\title{
THE GROWTH IMPACT OF DISASTERS IN DEVELOPING ASIA
}

Suzette Dagli and Benno Ferrarini

NO. 585

June 2019
ADB ECONOMICS WORKING PAPER SERIES 
ADB Economics Working Paper Series

\section{The Growth Impact of Disasters in Developing Asia}

Suzette Dagli and Benno Ferrarini

No. 585 | June 2019
Benno Ferrarini (bferrarini@adb.org) is a principal economist and Suzette Dagli (sdagli@adb.org) is an economics officer in the Economic Research and Regional Cooperation Department (ERCD) of the Asian Development Bank.

The authors are grateful to Michael Timbang for help with compiling the data, and to the attendees of a brown bag seminar held by ERCD for their helpful comments and suggestions for improvement on an earlier draft of this paper. 
(C) 2019 Asian Development Bank 6 ADB Avenue, Mandaluyong City, 1550 Metro Manila, Philippines

Tel +632632 4444; Fax +6326362444

www.adb.org

Some rights reserved. Published in 2019.

ISSN 2313-6537 (print), 2313-6545 (electronic)

Publication Stock No. WPS190224-2

DOI: http://dx.doi.org/10.22617/WPS190224-2

The views expressed in this publication are those of the authors and do not necessarily reflect the views and policies of the Asian Development Bank (ADB) or its Board of Governors or the governments they represent.

ADB does not guarantee the accuracy of the data included in this publication and accepts no responsibility for any consequence of their use. The mention of specific companies or products of manufacturers does not imply that they are endorsed or recommended by ADB in preference to others of a similar nature that are not mentioned.

By making any designation of or reference to a particular territory or geographic area, or by using the term "country" in this document, $A D B$ does not intend to make any judgments as to the legal or other status of any territory or area.

This work is available under the Creative Commons Attribution 3.0 IGO license (CC BY 3.0 IGO)

https://creativecommons.org/licenses/by/3.o/igo/. By using the content of this publication, you agree to be bound by the terms of this license. For attribution, translations, adaptations, and permissions, please read the provisions and terms of use at https://www.adb.org/terms-use\#openaccess.

This CC license does not apply to non-ADB copyright materials in this publication. If the material is attributed to another source, please contact the copyright owner or publisher of that source for permission to reproduce it. $\mathrm{ADB}$ cannot be held liable for any claims that arise as a result of your use of the material.

Please contact pubsmarketing@adb.org if you have questions or comments with respect to content, or if you wish to obtain copyright permission for your intended use that does not fall within these terms, or for permission to use the ADB logo.

Corrigenda to ADB publications may be found at http://www.adb.org/publications/corrigenda.

Notes:

In this publication, "\$” refers to United States dollars.

ADB recognizes "China" as the People's Republic of China.

The ADB Economics Working Paper Series presents data, information, and/or findings from ongoing research and studies to encourage exchange of ideas and to elicit comment and feedback about development issues in Asia and the Pacific. Since papers in this series are intended for quick and easy dissemination, the content may or may not be fully edited and may later be modified for final publication. 


\section{CONTENTS}

TABLES, FIGURES, AND BOX iv

ABSTRACT V V V V V V V

$\begin{array}{ll}\text { I. INTRODUCTION } & 1\end{array}$

II. DISASTERS IN DEVELOPING ASIA AND OTHER WORLD REGIONS 2

III. THE GROWTH IMPACT OF DISASTERS-REGRESSION ANALYSIS 8

$\begin{array}{ll}\text { IV. CONCLUSIONS } & 13\end{array}$

$\begin{array}{ll}\text { APPENDIX } & 15\end{array}$

$\begin{array}{lc}\text { REFERENCES } & 23\end{array}$ 


\section{TABLES, FIGURES, AND BOX}

\section{TABLES}

$1 \quad$ Generalized Method of Moments Regressions with Severe Disaster Dummies-World 11

$2 \quad$ Generalized Method of Moments Regressions with Severe Disaster Dummies- 12

Developing Regions

3 Generalized Method of Moments Regressions with Severe Disaster Dummies- 12

Developing Asia's Subregions $\quad 14$

A.1 List of Economies in Developing Asia and Subregions 15

A.2 Disaster Impact in Developing Asia, 1980-2017 15

A.3 Summary of Variables Used in Regression Analysis-Developing Asia Sample 16

A.4 Ordinary Least Squares Results with Severe Disaster Dummies 17

A.5 Generalized Method of Moments Regressions with above 50th Percentile Disaster 18 Dummies

A.6 Generalized Method of Moments Regression Results Using Alternative Specification 20 for Intensity

A.7 Rolling 5-Year Generalized Method of Moments Regressions with Severe Disaster $\quad 21$ Dummies

\section{FIGURES}

1 Total Number of Disasters, 1980-2017 3

2 Total Number of Disasters in Developing Asia Subregions, 1980-2017 4

3 Disaster Types, 1980-2017 5

$4 \quad$ Number of People Affected by Disasters Globally 25

$5 \quad$ Number of People Affected by Disasters-Developing Asia 6

6 Global Impact of Disasters-Damage and Losses 7

7 Disaster Impact: Material Losses-Developing Asia 7

$8 \quad$ Disaster Damage Relative to Population and Economic Size, 1980-2017 8

BOX

The Emergency Events Database and Its Suitability for Regression Analysis 


\begin{abstract}
This paper estimates the growth impact of disasters, with a focus on developing Asia and its subregions. It finds that severe disasters slow down annual growth in the Pacific island countries by between 1 and 2 percentage points on average. This should come as no surprise, given these economies' extreme exposure, structural vulnerability, and small size relative to the footprint of major natural hazards. The growth impact is less clear for other regions and worldwide, mainly because disaster effects tend to be highly localized and get diluted in the context of cross-country regressions with nationwide growth as the unit of analysis.
\end{abstract}

Keywords: developing Asia, disasters, economic growth, natural hazards

JEL codes: 047, Q51, Q54 


\section{INTRODUCTION}

When a natural hazard, such as an intense tropical storm or a strong earthquake, interacts with an exposed and vulnerable population, the ensuing disaster typically affects human lives and destroys infrastructure and other physical assets. Direct impacts, including mortality and morbidity, damages to fixed assets and capital, and losses of crops and raw material, are often followed by indirect impacts from foregone local economic activity and knock-on effects across the broader economy. The longerterm consequences may also entail distorted risk perceptions, health effects, and social network disruptions that can undermine a country's investment, development, and growth path (Noy, Ferrarini, and Park 2019).

Empirical literature tends to find human and economic losses from disasters that are in inverse relationship to the affected countries' levels of development, especially where governance is weak and resilience is low (Kahn 2005, Noy and duPont 2016). It also tends to confirm that disaster resilience is greatest for countries with diversified economies, strong institutions, cohesive social infrastructure, and sound policy frameworks to prevent or deal with disaster impacts such as through early warning systems and emergency plans (Toya and Skidmore 2007, Jaramillo 2007, Noy 2009, Aldrich and Sawada 2015).

The evidence about a causal link between disasters and economic growth is far from conclusive. Several studies find that disasters do not disrupt growth (e.g., Skidmore and Toya 2002, Cavallo et al. 2013). Others, such as Fomby, Ikeda, and Loayza (2009), show that floods of moderate intensity may even spur growth. More generally, their findings suggest that economic impacts depend on the intensity and type of disaster (e.g., hydrological versus geological) and which sectors are affected. Similar conclusions are reached in cross-country analyses such as Raddatz (2009), Loayza et al. (2012), and Felbermayr and Groeschl (2014). ${ }^{1}$

Such conclusions are consistent with the ambiguous predictions from growth theory: while a disaster may reduce the workforce and destroy human and physical capital, and thus slow growth considerably, the devastation of capital stock may boost marginal returns and spur economic expansion through innovation (Loayza et al. 2012). More realistically, though, empirical findings tend to be inconclusive because they focus on national or regional effects, which aggregate out the typically localized and more circumscribed effects of disasters, however devastating. Indeed, a number of studies demonstrate the extent to which regression analysis with a broad macroeconomic focus fails to pick up on the impact of disasters at the local level (Strobl 2011; Elliott, Strobl, and Sun 2015).

The cross-country empirical literature on the growth impact of disasters has taken mainly a global focus. Although the literature has been expanding steadily, a specific study on developing Asia and its subregions is currently missing. One recent exception is a study by Lee, Zhang, and Nguyen (2018), who focused on the Pacific island countries during 1995-2016, finding that severe disasters not only stifle economic growth in these countries, reducing gross domestic product (GDP) by 1.8 percentage points on average, but also deteriorate their fiscal and trade balances.

\footnotetext{
Felbermayr and Groeschl (2014) summarize the key characteristics of major empirical findings in the literature up to 2013.
} 
This paper aims to provide a more ample cross-country growth perspective on the impact of disasters in developing Asia. Focus on Asian subregions fills a gap in the existing cross-country empirical literature, which has estimated impacts mainly across broad aggregates, such as advanced or developing countries, or by continents. Focus on ADB's developing member countries also suits the paper's purpose as a background study for the Asian Development Outlook 2019 report, on "Strengthening Disaster Resilience" (ADB 2019). The paper is structured to first present the trends arising from the disaster records from 1980 onward, and to then discuss the results of a regression analysis that combines these records with macroeconomic and other country data to estimate the growth impacts of severe disasters across countries and over time.

\section{DISASTERS IN DEVELOPING ASIA AND OTHER WORLD REGIONS}

The Emergency Events Database (EM-DAT) provides a record of disaster impacts with near-universal coverage (Box). Developing Asia's comparably heavy exposure is evident. Between 1980 and 2017, EM-DAT contains more than 4,000 disasters records for developing Asia, a far higher number compared with sub-Saharan Africa, Central and South America, the Caribbean, or the Middle East and North Africa (Figure 1). Within the region, Southeast Asia, South Asia, and East Asia have the highest rates of occurrence, followed by the Pacific and Central Asia (Figure 2). Given that geographic size determines the frequency with which a certain region or country experiences disasters - the larger its national territory the more likely a country is to experience a disaster within a given period, everything else being equal, the incidence of disasters is disproportionally high in both the Caribbean and the Pacific, mainly because of the frequent occurrence of tropical cyclones at those latitudes. See Appendix Table A.1 for a detailed list of economies.

\section{Box: The Emergency Events Database and Its Suitability for Regression Analysis}

The Emergency Events Database (EM-DAT) of the Centre for Research on the Epidemiology of Disasters provides comprehensive information about the frequency, type, and intensity of disasters in terms of human and material losses, with near-global coverage. ${ }^{a}$ EM-DAT defines disasters as situations or events for which at least one of the following criteria holds true: 10 or more people are killed, 100 or more people are reported affected, a state of emergency is declared, international assistance is requested. ${ }^{\text {b Included are }}$ hydro-meteorological disasters, such as floods and storms; climatological disasters, such as droughts, extreme temperatures, and wildfires; geophysical disasters, such as earthquakes and volcanic eruptions; and biological disasters, such as epidemics and insect infestations. Also included in this database, but not in our analysis, are technological disasters, such as industrial and traffic accidents.

EM-DAT reports the number of people killed by a disaster, the number of people affected, and the amount of direct damages. However, data availability is scant, especially on material losses. For developing countries in Asia from 1980 onward, damage information is available for less than 40\% of the disasters reported. Estimates of people affected (mortality, morbidity, and otherwise harmed) are more readily available, and cover more than $80 \%$ of all the events affecting developing Asia (Central Asia, East Asia, the Pacific, South Asia, and Southeast Asia). According to EM-DAT, "affected" refers to the number of people injured, and those requiring immediate assistance or left homeless after a disaster. This is a rather vague concept, ranging from the severely injured to those requiring temporary relocation from a flood-affected area, for example.

continued on next page 
Relevant to the regression analysis for this paper, Felbermayr and Groeschl (2014) noted that the positive correlation between gross domestic product per capita and the probability of an event's inclusion in the database raises concerns about endogeneity. ${ }^{c}$ Also, it is commonly assumed that disaster records prior to 1980 are less reliable, especially in relation to developing countries, because of limited and inconsistent reporting of events and damages. To avoid these shortcomings to an extent, the analysis in this paper is limited to data from 1980 onward.

${ }^{a}$ Data for download and details about the EM-DAT database are available at https://www.emdat.be.

${ }^{\mathrm{b}}$ Noy (2015) cautions that these thresholds for recording a disaster are in absolute rather than relative terms; they are the same whether an event affects, say, 200 people in a territory as vast as India or as tiny as the Marshall Islands. As a result, events of significant impact to a small country may not be reported. Cavallo and Noy (2011) describe EM-DAT as the only internationally comparable and available data on disasters, but one that collects limited information on "too many events."

"Other issues arise out of the impossibility within the database of distinguishing whether any data point is zero or unreported. Source: Authors.

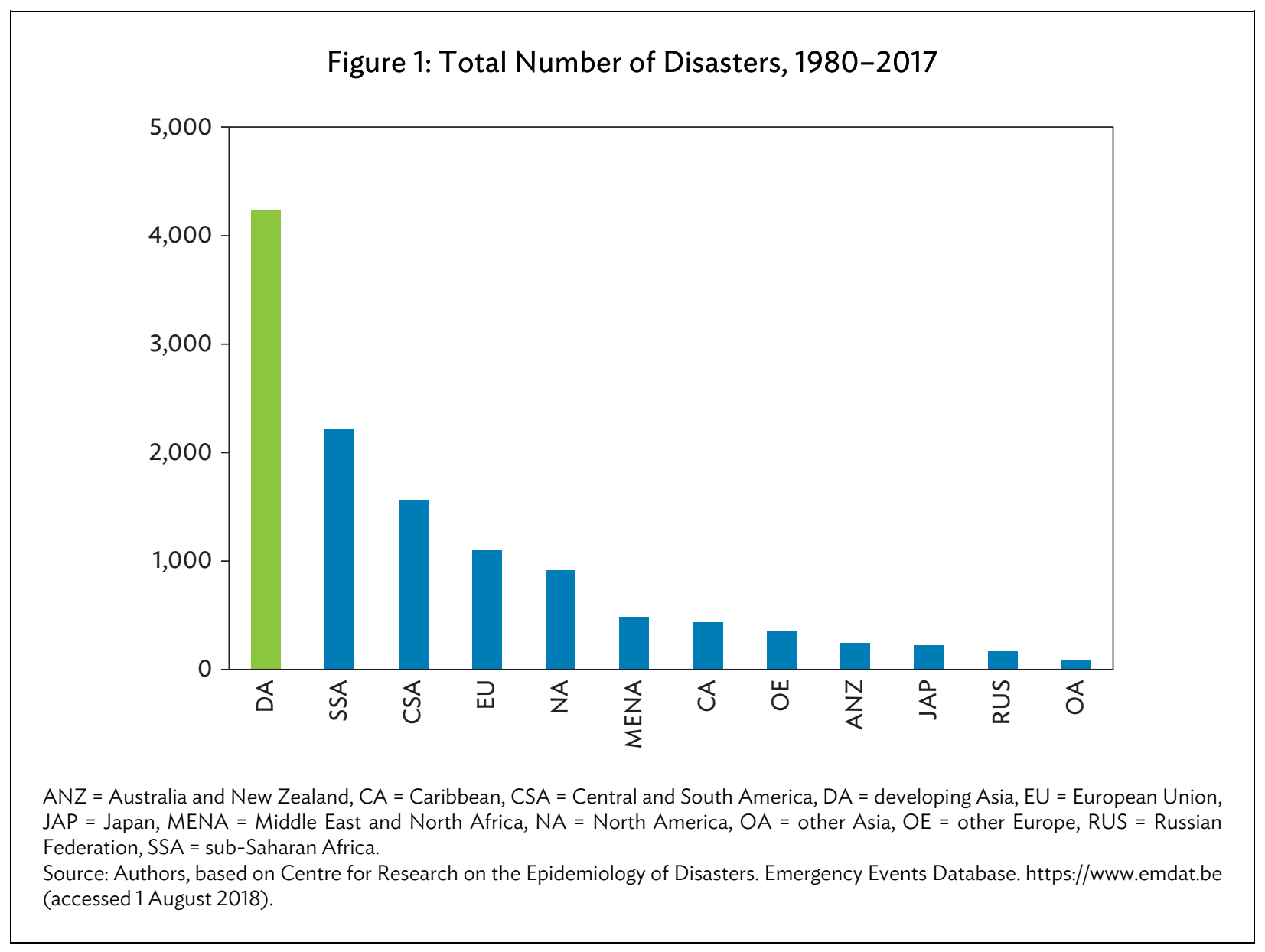


Figure 2: Total Number of Disasters in Developing Asia Subregions, 1980-2017

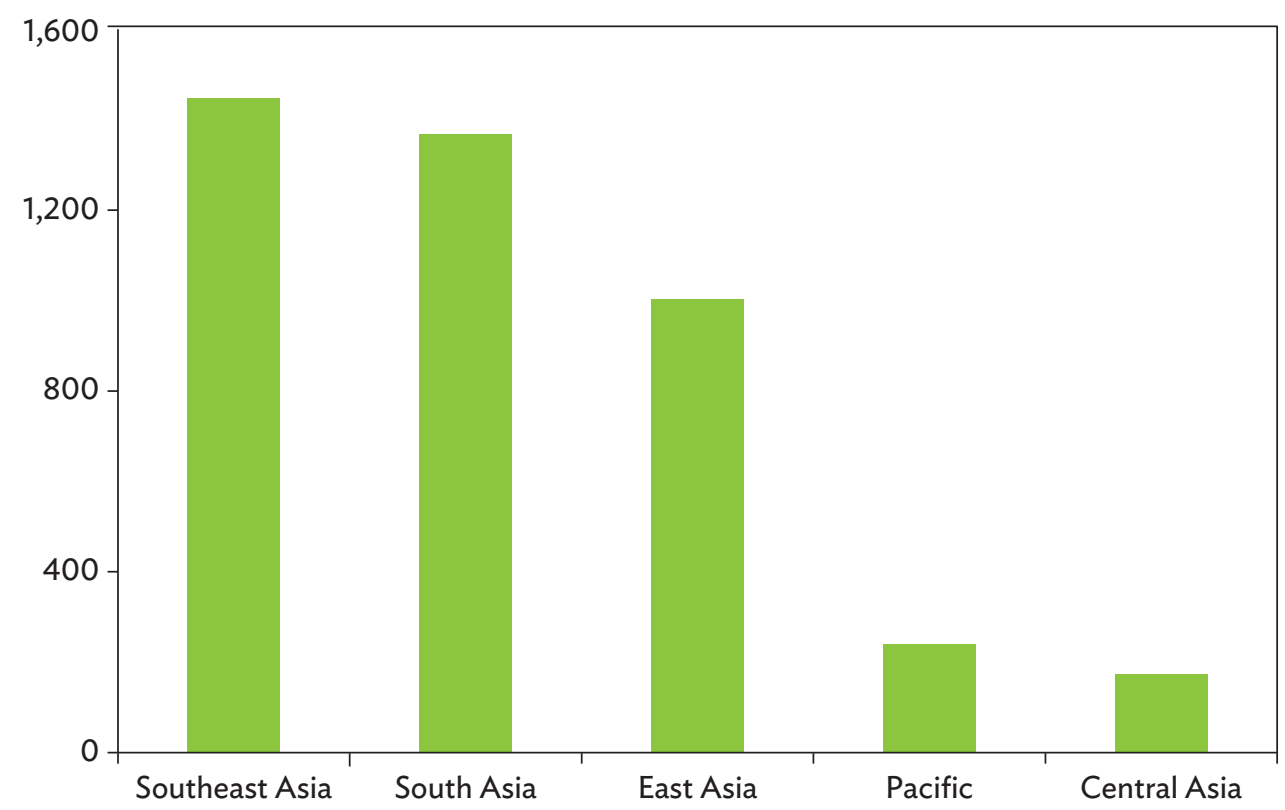

Source: Authors, based on Centre for Research on the Epidemiology of Disasters. Emergency Events Database. https://www.emdat.be (accessed 1 August 2018).

Floods and storms (both weather-related events) account for the largest share of disasters worldwide and for most regions, including developing Asia (Figures $3 \mathrm{a}$ and $3 \mathrm{~b}$ and Appendix Table A.2). Next most frequent are earthquakes, tsunamis, and volcanic eruptions (geophysical hazards); followed by extreme temperatures, droughts, and wildfires. Epidemics occur most frequently in subSaharan Africa but are also a significant problem in developing Asia and several other regions. Within developing Asia, floods are relatively more frequent in Central Asia and South Asia, while storms make up the bulk of disasters in East Asia and the Pacific. Epidemics are relatively more frequent in Southeast Asia.

In terms of their impact, disasters affect far more people in developing Asia than elsewhere (Figure 4). In part, this is because of the vast populations of disaster-prone countries-especially India and the People's Republic of China, but also Indonesia and the Philippines. The number of Asians affected by disasters exceeded 300 million in several years during 1980-2017 and reached more than 600 million in 2002 alone (Figure 5). The numbers are much smaller in the other regions with a few exceptions, such as in 2016, when storms affected more than 85 million people in the United States (US). However, high-impact numbers are not determined by Asia's large populations alone. Even when normalized by total population, the number of Asians affected by disasters caused by natural hazards during 2000-2018 is 4 times higher compared with the rest of the world. So Asian populations are not only large, but also their exposure to natural hazards appears to be disproportionally high. 
Figure 3: Disaster Types, 1980-2017

(a) Global

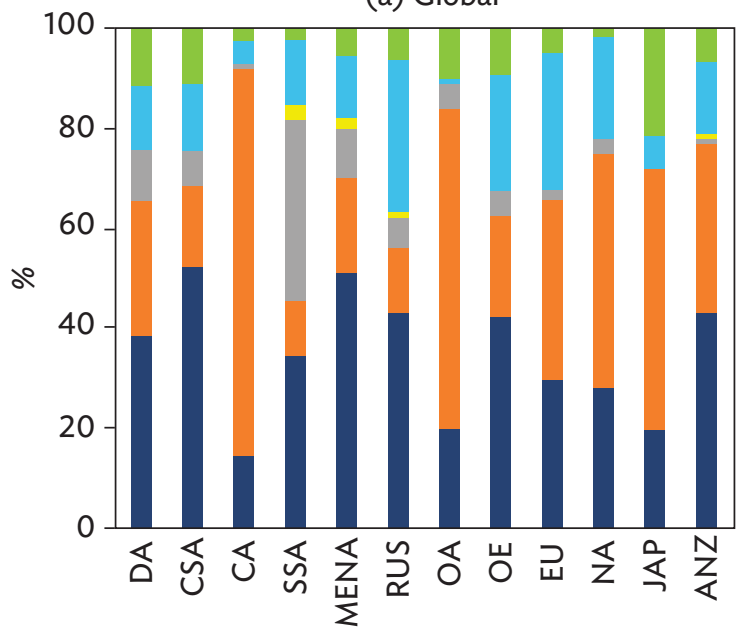

Floods, landslides, and mass movements Storms

Earthquakes, tsunamis, and volcanic eruptions (b) Developing Asia

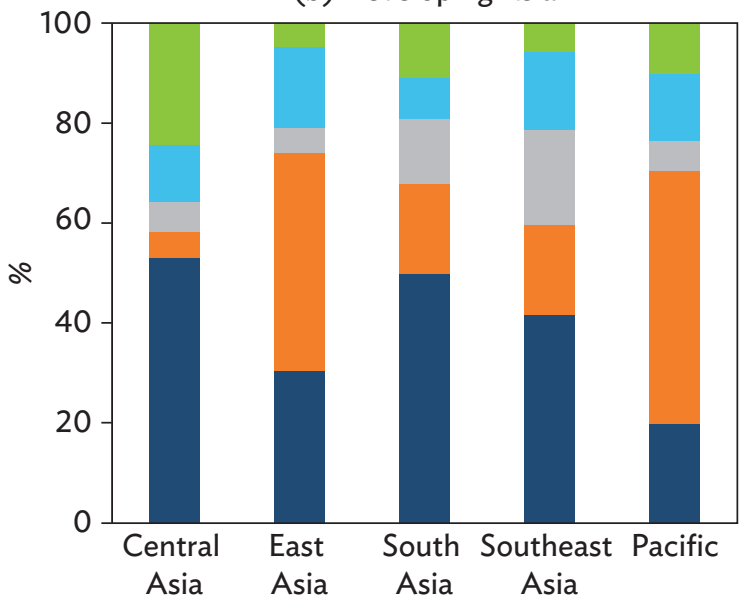

Epidemics

Extreme temperatures, droughts, and wildfires

Insect infestations

ANZ $=$ Australia and New Zealand,$C A=$ Caribbean, $C S A=$ Central and South America, DA $=$ developing Asia, EU = European Union, $\mathrm{JAP}=$ Japan, MENA = Middle East and North Africa, NA = North America, $\mathrm{OA}=$ other Asia, $\mathrm{OE}=$ other Europe, RUS $=$ Russian Federation, SSA = sub-Saharan Africa.

Source: Authors, based on Centre for Research on the Epidemiology of Disasters. Emergency Events Database. https://www.emdat.be (accessed 1 August 2018).

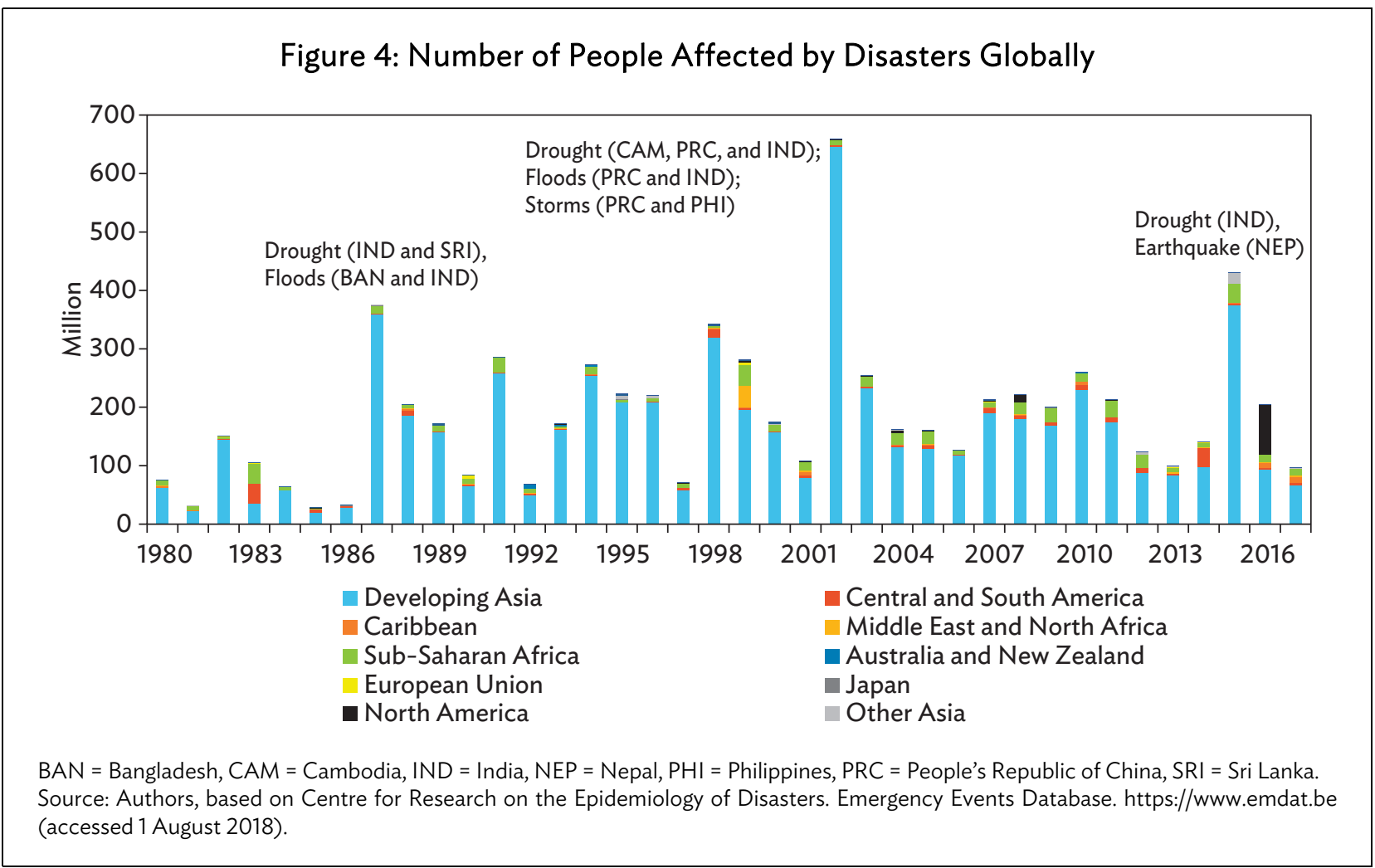




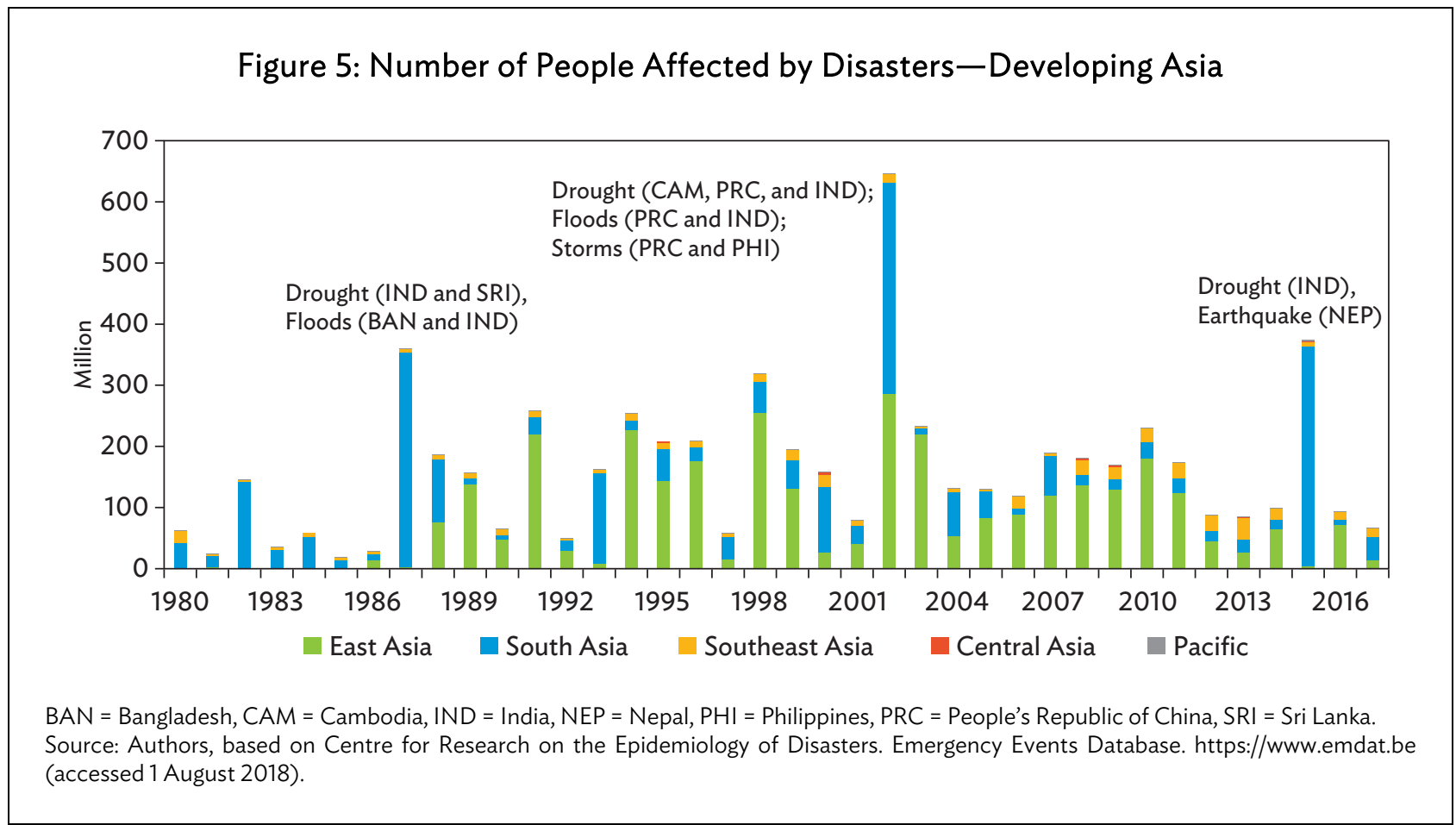

The opposite holds true for total damage from disasters, which is highest in the advanced countries, where exposure is greatest in terms of asset value, such as buildings and infrastructure. "Total damage" in EM-DAT estimates the value of all damages and economic losses directly or indirectly related to the disaster. This tends to be highest in countries where severe and frequent hazards combine with a significant exposure in terms of assets, such as Japan and the US (Figure 6). Within the developing world, developing Asia experienced the highest material damage, especially East Asia (Figure 7). ${ }^{2}$

To gauge the relative impact of disasters, EM-DAT is combined with World Bank data on population and gross domestic output. In relative terms, impact is highest for the Caribbean, followed by developing Asia, sub-Saharan Africa, and the rest of the developing world (Figure 8a). During 19802017 on average, disasters affected about 5\% of developing Asia's population and assets, compared with about $0.1 \%$ or less in Japan and North America. Within developing Asia, the strongest impacts are felt in the Pacific, where more than $13 \%$ of population and assets are affected by disasters each year on average - a much higher share compared with the other subregions (Figure 8b).

2 One apparent exception and anomaly in Figure 6 is the case of the Caribbean in 2017, which reflects the devastation to Puerto Rico brought about by Hurricane Maria in September that year. 
Figure 6: Global Impact of Disasters-Damage and Losses

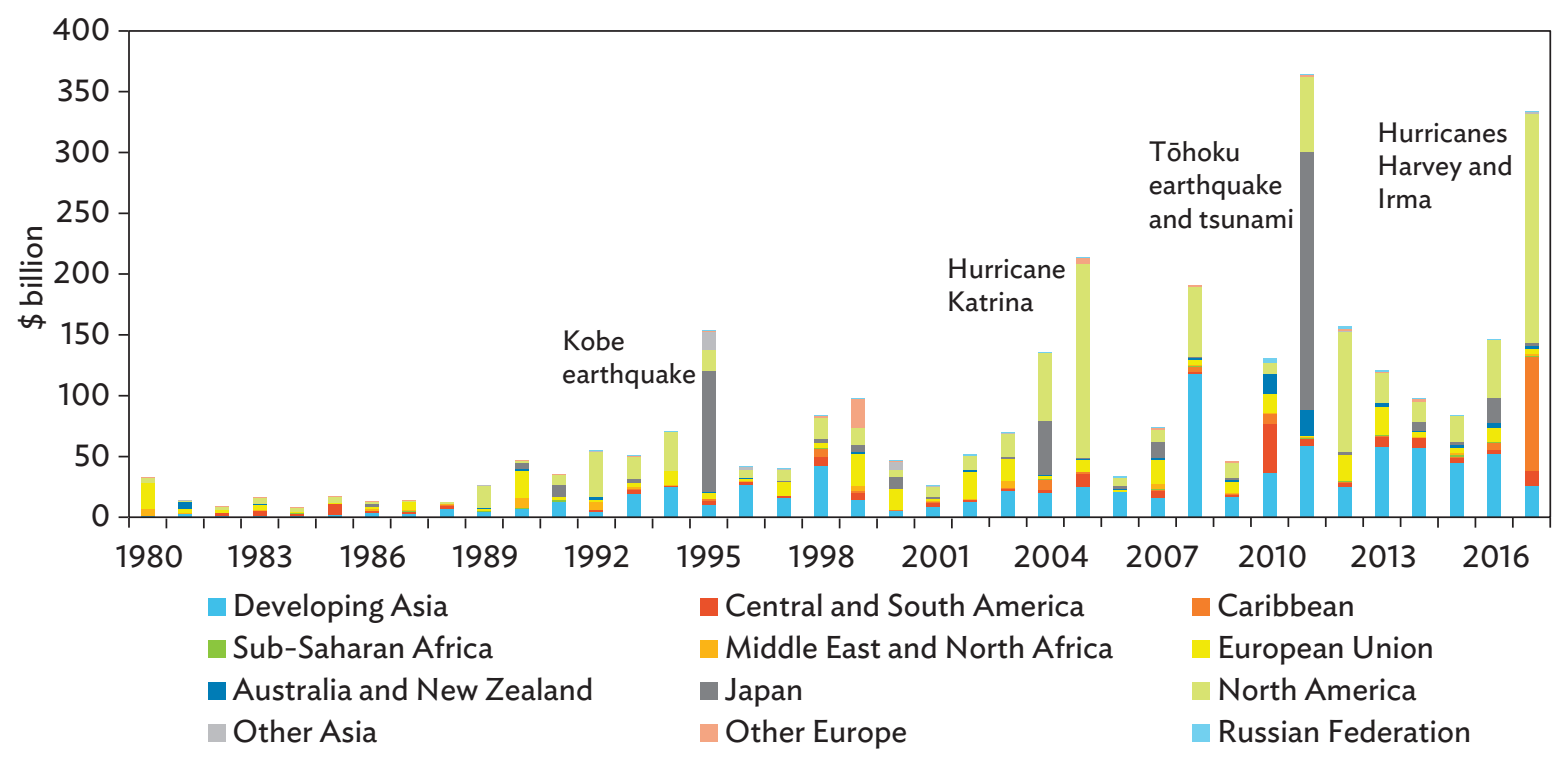

Source: Authors, based on Centre for Research on the Epidemiology of Disasters. Emergency Events Database. https://www.emdat.be (accessed 1 August 2018).

Figure 7: Disaster Impact: Material Losses-Developing Asia

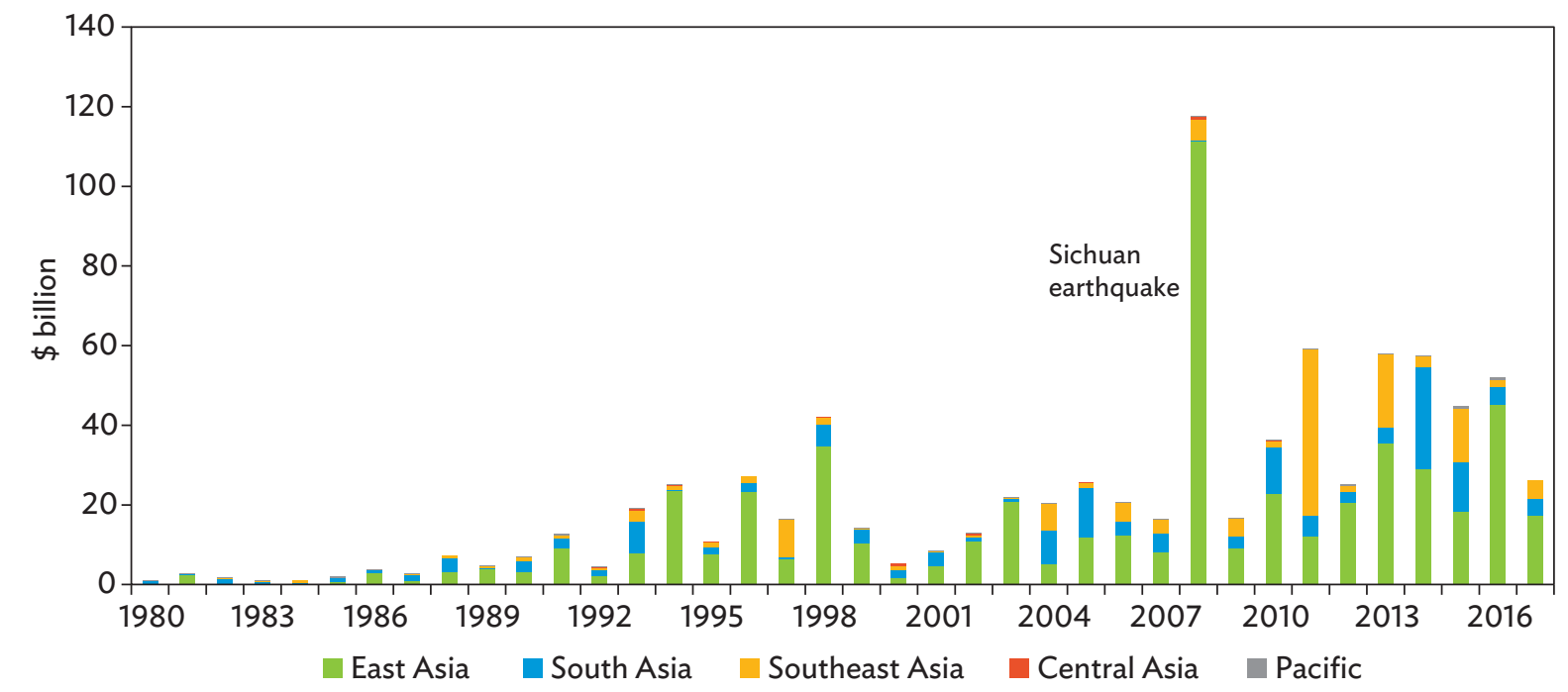

Source: Authors, based on Centre for Research on the Epidemiology of Disasters. Emergency Events Database. https://www.emdat.be (accessed 1 August 2018). 
Figure 8: Disaster Damage Relative to Population and Economic Size, 1980-2017

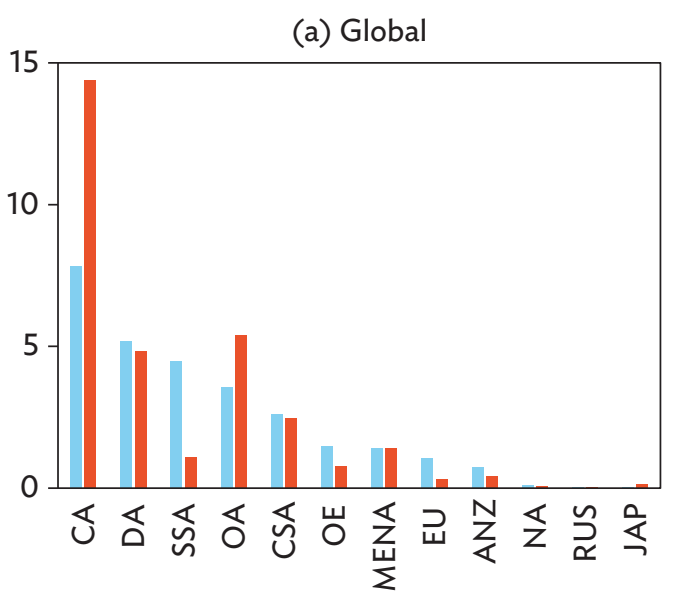

Affected population (\% of total population)

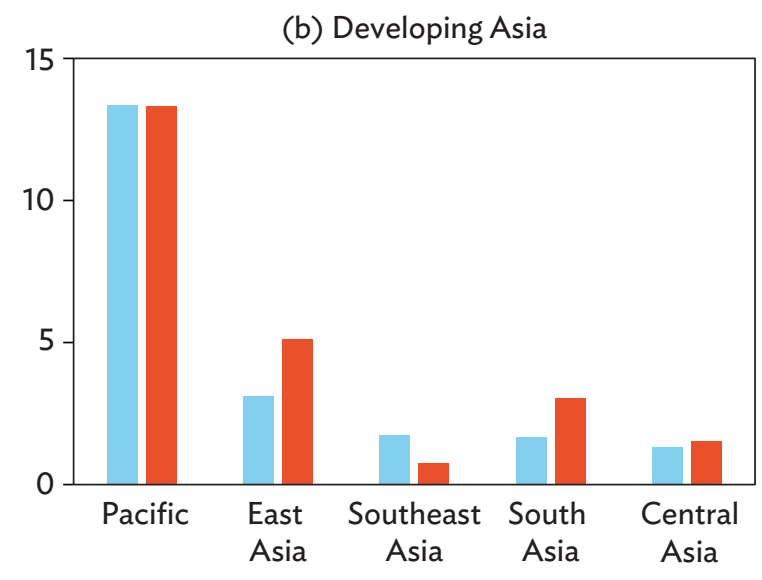

Total damage and economic losses (\% of GDP)

$\mathrm{ANZ}=$ Australia and New Zealand, $\mathrm{CA}=$ Caribbean, $\mathrm{CSA}=$ Central and South America, $\mathrm{DA}=$ developing Asia, EU $=$ European Union, $\mathrm{GDP}=$ gross domestic product, $\mathrm{JAP}=$ Japan, MENA = Middle East and North Africa, NA = North America, OA $=$ other Asia, OE $=$ other Europe, RUS = Russian Federation, SSA = sub-Saharan Africa.

Source: Authors, based on Centre for Research on the Epidemiology of Disasters. Emergency Events Database. https://www.emdat.be (accessed 1 August 2018).

\section{THE GROWTH IMPACT OF DISASTERS-REGRESSION ANALYSIS}

To investigate the growth impacts of disasters in developing Asia and its subregions compared with the rest of the world, cross-country growth regressions are based on the EM-DAT annual disaster data for 172 countries over 38 years (1980-2017) combined with the World Banks' World Development Indicators annual data on population; land area; GDP (real and nominal, local currencies and US dollars); inflation; total imports and exports; financial depth (domestic credit to the private sector by banks as a share of GDP); and the net barter terms of trade index. Data on inflation for the Pacific island countries-which are scarcely available from these main sources-are supplemented by data from the Asian Development Outlook by the Asian Development Bank and World Economic Outlook by the International Monetary Fund. Appendix Table A.3 describes and summarizes the variables used in the regression analysis.

The typical empirical strategy is to follow the standard cross-country growth regression framework (Mankiw, Romer, and Weil 1992; Islam 1995), as has been done by much of the previous literature (e.g., Skidmore and Toya 2002, Noy 2009, Loayza et al. 2012), with the following specification:

$$
\ln Y_{i, t}^{k}-\ln Y_{i, t-1}^{k}=\alpha \ln y_{i, t-1}^{k}+\delta D_{i, t}^{k}+\beta X_{i, t}^{k}+\mu_{t}+\gamma_{i}+\varepsilon_{i, t}
$$

where, for disaster type $k$, country $i$, and year $t$ : $\ln Y_{i, t}-\ln Y_{i, t-1}$ is (log) growth of real GDP; $\ln y_{i, t-1}$ is (log) GDP per capita, to control for convergence; $D_{i, t}$ is a measure or indicator variable capturing the intensity or occurrence of disasters; $X_{i, t}$ is a vector of control variables to account for structural aspects (population density for economic and geographic size), policy indicators (openness to trade), and external factors (shocks to a country's terms of trade); $\gamma_{i}, \mu_{t}$ account for country- and time- 
specific effects, respectively, to allow for shocks that may commonly affect all countries' rate of growth in any given year, or any country individually.

The measure to capture disaster impacts follows the common method set out in IMF (2003), and adopted also by Fomby, Ikeda, and Loayza (2009) and Loayza et al. (2012). This accounts for both the frequency and intensity of disasters by computing the weighted sum of the number of casualties (killed, given full weight) and the number of people otherwise affected (affected, given 0.3 weight), as a ratio to total population (to allow for cross-country comparison):

$$
\text { intensity }_{d, i, t}^{k}=\frac{\text { killed d }_{d, i, t}^{k}+0.3 * \text { affected }_{d, i, t}^{k}}{\text { population }_{i, t}}
$$

To test for the robustness of the results for the intensity measure, regressions will also employ an alternative weight of 0.1 , instead of 0.3 , of the number of people affected in equation (2). Intensity is thus gauged in relation to each disaster type $k$ (all disasters, storms, earthquakes, volcanic eruptions, etc.), and computed across all the disasters $d$ that took place in each country $i$ during year $t$. Intensity is then ranked by decreasing order, and values above the 75th percentile are mapped into an intensity dummy, $D_{d, i, t}^{k, 75}$, to capture the effects of only the most severe among the disasters:

$$
D_{d, i, t}^{k, 75}=1 \text { if intensity } y_{d, i, t}^{k}>p(75)
$$

and zero otherwise. $p(75)$ is the value of intensity at the 75th percentile, and serves as a threshold, where only values above $p(75)$ are considered severe disasters, and where $D_{d, i, t}^{k, 75}=1$. This approach mirrors Lee, Zhang, and Nguyen (2018), who found that the GDP and population impact of disasters turns significant at about the 75th percentile threshold.

Following the same procedure, impact measures are derived as well from economic damage ( $\%$ of GDP) and the number of affected population ( $\%$ of total population). The variables affected $\left(A_{d, i, t}^{k, 75}\right)$ and damage $\left(E_{d, i, t}^{k, 75}\right)$, are ranked in descending order and mapped into dummies to capture all values above the 75 th percentile cutoffs. Also included in the analysis is the impact of disasters above the 50th percentile cutoff and constructed the $D_{d, i, t}^{k, 50}$ dummy for intensity, $A_{d, i, t}^{k, 50}$ for affected population, and $E_{d, i, t}^{k, 50}$ for economic damage, similar to equation (3).

Estimation of equation (1) is somewhat problematic because disaster impact $D_{i, t}^{k}$ (especially economic damage) and most of the controls in $X_{i, t}^{k}$ (e.g., trade openness) are endogenous with economic growth, which raises the issue of reverse causation that may invalidate the regression results. To deal with these potential sources of bias that can cause inconsistency in the coefficients of panel regression, this paper adopts the generalized method of moments (GMM) estimator, following similar studies' empirical strategy, e.g., Lee, Zhang, and Nguyen (2018) and Loayza et al. (2012). Essentially, GMM consists of differencing equation (1) to control for unobserved country effects. In addition, it uses lagged dependent variables as internal instruments that are added to the fitted model, such that the resulting error term is not serially correlated (Arellano and Bond 1991, Arellano and Bover 1995).

The difference GMM model is fitted to equation (1) for a total of 172 countries and for each of the developing regions in turn: developing Asia, the Caribbean, Central and South America, the Middle East and North Africa, and sub-Saharan Africa. The developing Asia sample is then further broken 
down into the usual five subregional groupings: Central Asia, East Asia, the Pacific, South Asia, and Southeast Asia.

Baseline regressions include GDP growth as the dependent variable, the control variables, plus one disaster indicator, which are included alternatively. Regressions are estimated to include the natural-hazard-induced disasters recorded in EM-DAT, as well as for each of the $k$ disaster types individually: floods, storms, earthquakes and tsunamis, landslides, epidemics, droughts, wildfires, extreme temperatures, and volcanic eruptions. ${ }^{3}$ Each of the regressions includes a full set of year dummies to control for period effects common to all countries. Because of the limited number of observations-especially when regressions take each of the Asian subregions in turn-the number of instruments is best kept low, thus only two lags are included in regressions. The lag of (log) real GDP per capita and (log) population density are set as GMM instruments, while the rest enter the GMM specification as instrumental variable instruments.

Altogether, 660 GMM regressions are estimated: 10 (by disaster types: all, floods, storms, etc.) x 11 (by region: World, developing Asia, the Caribbean, Central and South America, the Middle East and North Africa, sub-Saharan Africa, Central Asia, East Asia, the Pacific, South Asia, and Southeast Asia) $\times 3$ (by disaster indicators: intensity, damage, and affected population) $\times 2$ (by disaster indicator: top $25 \%$ and top 50\%). While extensive reporting of results is impractical within the space constraints of this paper, the core findings are summarized in Tables 1-3.

Table 1 shows the estimated coefficients from regressions, except period dummies, which are omitted. The dependent variable is GDP growth (its logarithm), and independent variables include the disaster dummies alternatively-intensity, damage, affected-plus the control variables for 172 countries. The aggregate effect of severe (top 25\%) disasters on GDP growth is negative and significant, yet small. When measured in terms of intensity $\left(D_{d, i, t}^{k, 75}\right)$ or affected population $\left(A_{d, i, t}^{k, 75}\right)$, disasters cause GDP growth to decline by 0.5 percentage points on average. When measured in terms of economic losses $\left(E_{d, i, t}^{k, 75}\right)$, disasters slow GDP growth by 0.9 percentage points on average. Although these results are based on the whole sample, they appear to be reflective mainly of the Caribbean and Central and South America, which display the most negative and significant coefficients among the regional regressions.

The coefficients of the control variable are in line with the growth literature's general finding: GDP growth and GDP per capita levels are in a significant negative relation to each other, implying that there is income convergence across countries. Lagged population density has the expected positive sign but lacks statistical significance. The coefficients of trade openness and terms-of-trade movements are positive and statistically significant. Financial depth takes a negative sign, which implies that higher bank credit within the domestic economy has hampered growth on average across countries. This too appears plausible, the literature being largely inconclusive about the direction of the relationship between financial development and economic growth (Levine 1997). Finally, the coefficient of inflation-a proxy for macroeconomic vulnerability-is not statistically significant.

3 Dry mass movements and insect infestations have been dropped as individual categories because of the low incidence of events (see Appendix Table A.2, on developing Asia). 
Table 1: Generalized Method of Moments Regressions with Severe Disaster Dummies-World

\begin{tabular}{|c|c|c|c|}
\hline Dependent Variable: Log (GDP Growth) ${ }_{t}$ & (1) & $(2)$ & (3) \\
\hline Top 25\% intensity $t_{t}$ & $\begin{array}{c}-0.0047^{*} \\
(0.0027)\end{array}$ & & \\
\hline Top 25\% damage (\% of GDP) ${ }_{t}$ & & $\begin{array}{r}-0.0088^{* *} \\
(0.0035)\end{array}$ & \\
\hline Top $25 \%$ affected (\% of population) $t$ & & & $\begin{array}{c}-0.0050^{*} \\
(0.0028)\end{array}$ \\
\hline Log (real GDP per capita) $)_{t-1}$ & $\begin{array}{r}-0.1031^{* * *} \\
(0.0142)\end{array}$ & $\begin{array}{r}-0.1030^{* * *} \\
(0.0142)\end{array}$ & $\begin{array}{r}-0.1030^{* * *} \\
(0.0142)\end{array}$ \\
\hline $\log (\text { population density) })_{t-1}$ & $\begin{array}{r}0.0182 \\
(0.0186)\end{array}$ & $\begin{array}{r}0.0185 \\
(0.0186)\end{array}$ & $\begin{array}{r}0.0182 \\
(0.0186)\end{array}$ \\
\hline $\log (\text { inflation })_{t-1}$ & $\begin{array}{r}0.0071 \\
(0.0053)\end{array}$ & $\begin{array}{r}0.0070 \\
(0.0053)\end{array}$ & $\begin{array}{r}0.0070 \\
(0.0053)\end{array}$ \\
\hline Trade openness $t_{t-1}$ & $\begin{array}{c}0.0585^{* * *} \\
(0.0079)\end{array}$ & $\begin{array}{c}0.0583^{* * *} \\
(0.0079)\end{array}$ & $\begin{array}{c}0.0584^{* * *} \\
(0.0079)\end{array}$ \\
\hline Terms of trade growth $_{t-1}$ & $\begin{array}{c}0.0134^{* *} \\
(0.0064)\end{array}$ & $\begin{array}{c}0.0133^{* *} \\
(0.0064)\end{array}$ & $\begin{array}{c}0.0134^{* *} \\
(0.0064)\end{array}$ \\
\hline Financial depth $t_{t-1}$ & $\begin{array}{r}-0.0354^{* * *} \\
(0.0122)\end{array}$ & $\begin{array}{r}-0.0342^{* * *} \\
(0.0122)\end{array}$ & $\begin{array}{r}-0.0356^{* * *} \\
(0.0122)\end{array}$ \\
\hline Time fixed effects & Yes & Yes & Yes \\
\hline Number of observations & 3,666 & 3,666 & 3,666 \\
\hline AR(2) $p$ value & 0.2054 & 0.2233 & 0.2001 \\
\hline
\end{tabular}

$\mathrm{AR}=$ autoregressive model, GDP = gross domestic product.

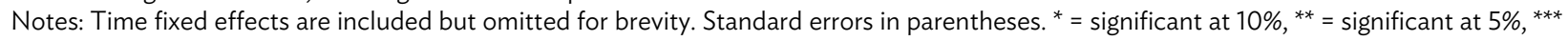
= significant at $1 \%$.

Source: Authors.

The Sargan and second-order autoregressive (AR[2]) tests of the GMM regressions satisfy requirements for identification and autocorrelation. Values reported for $A R(2)$ are $p$ values for secondorder autocorrelated disturbances in the first differenced equation. The test results suggest that there is no evidence of significant second-order autocorrelation. In addition, a simple exogeneity test shows that real GDP per capita and population density are not strictly exogenous to GDP growth, suggesting that ordinary least squares (OLS) estimation would be biased. Further, the correlation between the real GDP per capita and population density with the residual of equation (1) is not zero. Nevertheless, OLS regressions with country and time fixed effects are a relevant benchmark comparator and are found to be largely consistent with the GMM estimates (Appendix Tables A.4a-4c).

Table 2 turns to the regional regressions, with specifications similar to Table 1. For brevity, the coefficients of the control variables and time fixed effects are now omitted. Severe disasters, in terms of damage, are shown lowering GDP growth in developing Asia by about 0.6 percentage points on average. However, the regressions with the intensity and affected dummies yield results that are not statistically significant. A more consistent result is found for the Caribbean and Central and South America, where all the disaster dummies are statistically significant and negative: severe economic damage from disasters slows GDP growth by 1.8 percentage points on average in the Caribbean and by 
1.5 percentage points in Central and South America. ${ }^{4}$ By contrast, the results for the Middle East and North Africa and sub-Saharan Africa are not statistically significant.

The reason for weak evidence in relation to developing Asia as a region can be evinced from Table 3, which shows regression results at the subregional level. Essentially, evidence is mixed, and thus is canceled out at the more aggregate level. Results are not statistically significant for Central Asia, East Asia, and South Asia, and partially significant for Southeast Asia, depending on which disaster dummy is used in the regressions. The Pacific stands out, where evidence is strongest and most consistent of a negative and statistically significant effect of disasters on growth, whether it is measured by intensity, economic damage, or affected population. On average, severe disasters reduce economic growth in the Pacific by between 1.1 and 1.7 percentage points.

Table 2: Generalized Method of Moments Regressions with Severe Disaster DummiesDeveloping Regions

\begin{tabular}{lrrrrr}
\hline $\begin{array}{l}\text { Dependent Variable: } \\
\text { Log (GDP Growth) } t\end{array}$ & $\begin{array}{c}\text { Developing } \\
\text { Asia }\end{array}$ & Caribbean & $\begin{array}{c}\text { Central and } \\
\text { South } \\
\text { America }\end{array}$ & $\begin{array}{c}\text { Middle East } \\
\text { and North } \\
\text { Africa }\end{array}$ & $\begin{array}{c}\text { Sub-Saharan } \\
\text { Africa }\end{array}$ \\
\hline Top 25\% intensity $t$ & 0.0013 & $-0.0164^{* * *}$ & $-0.0098^{* * *}$ & -0.0167 & -0.0031 \\
& $(0.0029)$ & $(0.0060)$ & $(0.0029)$ & $(0.0300)$ & $(0.0044)$ \\
Top 25\% damage (\% of GDP) $t$ & $-0.0063^{*}$ & $-0.0180^{* * *}$ & $-0.0154^{* * *}$ & -0.0043 & 0.0006 \\
& $(0.0033)$ & $(0.0067)$ & $(0.0035)$ & $(0.0270)$ & $(0.0098)$ \\
Top 25\% affected (\% of population) $t$ & 0.0030 & $-0.0183^{* * *}$ & $-0.0113^{* * *}$ & -0.0216 & -0.0039 \\
& $(0.0029)$ & $(0.0062)$ & $(0.0030)$ & $(0.0327)$ & $(0.0046)$ \\
Number of observations & 713 & 168 & 605 & 336 & 1,174 \\
\hline
\end{tabular}

GDP = gross domestic product.

Notes: Full results are omitted for brevity. Standard errors in parentheses. ${ }^{*}=$ significant at $10 \%,{ }^{* *}=$ significant at $5 \%,{ }^{* *}=$ significant at $1 \%$.

Source: Authors.

\section{Table 3: Generalized Method of Moments Regressions with Severe Disaster Dummies- Developing Asia's Subregions}

\begin{tabular}{lcrrrr}
\hline $\begin{array}{l}\text { Dependent Variable: } \\
\text { Log (GDP Growth) } t\end{array}$ & Central Asia & East Asia & \multicolumn{1}{c}{ Pacific } & South Asia & Southeast Asia \\
\hline Top 25\% intensity ${ }_{t}$ & 0.0143 & -0.0069 & $-0.0171^{* * *}$ & -0.0014 & 0.0057 \\
& $(0.0141)$ & $(0.0100)$ & $(0.0057)$ & $(0.0040)$ & $(0.0037)$ \\
Top 25\% damage (\% of GDP) ${ }_{t}$ & -0.0142 & 0.0042 & $-0.0141^{* *}$ & -0.0032 & $-0.0105^{* *}$ \\
& $(0.0148)$ & $(0.0088)$ & $(0.0064)$ & $(0.0054)$ & $(0.0042)$ \\
Top 25\% affected (\% population) $)_{t}$ & 0.0143 & -0.0069 & $-0.0113^{* *}$ & 0.0014 & 0.0052 \\
& $(0.0141)$ & $(0.0100)$ & $(0.0057)$ & $(0.0042)$ & $(0.0036)$ \\
Number of observations & 90 & 105 & 94 & 180 & 244 \\
\hline
\end{tabular}

GDP = gross domestic product.

Notes: Full results are omitted for brevity. Standard errors in parentheses. ${ }^{*}=$ significant at $10 \%,{ }^{* *}=$ significant at $5 \%,{ }^{* *}=\operatorname{significant}$ at $1 \%$. Source: Authors.

4 The disaster impacts found here for the Caribbean are similar to those in Bello (2017). 
The regression results are tested for robustness to alternative specifications. A first robustness test replaces the 25th top disaster dummies with those including the full upper 50th percentile of disasters ranked by intensity $\left(D_{d, i, t}^{k, 50}\right)$, population affected $\left(A_{d, i, t}^{k, 50}\right)$, and economic damage $\left(E_{d, i, t}^{k, 50}\right)$. Appendix Tables A.5a-5c-corresponding to the baseline regressions in Tables 1-3, respectivelysuggest that, although the results are generally consistent with the earlier regressions, the statistical significance of the estimated disaster coefficients is now generally weaker or insufficient altogether. For example, in Appendix Table A.5a, while still negative, the coefficients of the disaster dummies are not statistically significant. That is, compared to the top $25 \%$ most severe disasters, the broader inclusion of events weakens the statistical conclusiveness about their impact on growth in the world sample. Similarly, the regional regression results in Appendix Table A.5b are qualitatively similar for the Caribbean and Central and South America, but not for developing Asia, where the disaster coefficient is not statistically significant. Overall, then, there seems to be no strong supporting evidence of any significant growth impact of disasters across developing Asia as a whole, except for the strongest among these events. In relation to the subregional regressions, Appendix Table A.5c shows that for the Pacific, disasters that caused moderate to severe economic damage are still found to reduce GDP growth-by an estimated 1.1 percentage points on average-while the coefficients of the other disaster dummies are not statistically significant.

The second in the battery of robustness tests involves the intensity dummy, which is now computed with a weight of 0.1 on the number for affected population, instead of 0.3. Appendix Table A.6 reports the regression results, which are confirmed robust.

The third test consists of regressions on medium-term economic growth, specified as a rolling 5 -year period, instead of annual growth. ${ }^{5}$ In essence, this involves estimating the impact on annual GDP growth of disasters that happened 5 years earlier, with the same controls as in equation (1), plus a variable to control for the policy-response effect in the form of foreign aid. It is assumed that foreign aid would have an impact on medium-term growth outcomes, especially during and after disaster events. The results confirm a negative growth impact of disasters in the Caribbean in the medium term, but not for developing Asia (Appendix Tables A.7a-7c). With the inclusion of foreign aid in the model, a negative relationship between disaster and growth in the medium term persists, and this finding is especially robust for the Caribbean.

\section{CONCLUSIONS}

This paper assessed the human and material impact of natural-hazard-induced disasters across countries and over time, based on historical records in EM-DAT from 1980 onward. Developing Asia stands out as the region that has not only experienced the highest frequency of natural hazards but has also suffered the largest effects in terms of the number of people affected. During 1980-2017, disasters affected about $5 \%$ of developing Asia's population and assets on average, and only about $0.1 \%$ or less of people and assets in Japan and North America. Within developing Asia, the strongest impacts are felt in the Pacific, where disasters on average affect more than $13 \%$ of people and assets each year. This is significantly higher compared with the rest of Asia, testifying to the fact that, accounting for economic size and population, disasters impact the smallest and most exposed of economies most heavily, especially the small island countries located in the Caribbean and the Pacific.

5 A rolling 5-year period is used in regressions instead of 5-year period (average) because of a rather limited number of observations. 
From regressions on a sample spanning 172 countries and the years 1980-2017, results show that severe disasters-i.e., the strongest $25 \%$ among disasters in terms of the number of people affected-cause GDP growth to decline by 0.5 percentage points worldwide, on average. The strongest $25 \%$ of disasters in terms of total damage are found to have a larger impact on GDP growth, averaging 0.9 percentage points. Regional regressions suggest that the average impact of disasters is highest in the Caribbean (a decline in GDP growth of 1.8 percentage points) and Central and South America (1.5 percentage points). The growth impact is both less pronounced and not as statistically significant in developing Asia (0.6 percentage points), and even less so in both sub-Saharan Africa and the Middle East and North Africa.

Despite disasters' heavy toll in developing Asia in terms of people affected and damages caused, growth in the region appears to be affected only mildly, and then only by the most catastrophic of events. However, there is much variation within the region. Growth in the Pacific island countries, in particular, has been found to slow the most from disasters by between 1.1 and 1.7 percentage points on average, depending on whether impacts are measured by intensity, economic damage, or affected population. This should come as no surprise. Similar to the Caribbean, the small island countries in the Pacific are known to be highly exposed and vulnerable to disasters because of their small size, remoteness, and limited diversification of resources. Other Asian subregions are far less affected: some evidence of negative growth impacts is found in Southeast Asia, but there are no significant results for Central Asia, East Asia, and South Asia.

The results are generally robust to various specification tests, such as OLS regressions instead of GMM, or computational changes to the disaster dummies. However, the results are quite sensitive to the inclusion of a broader segment of disasters ranked by impact. When regressions include dummies capturing the top $50 \%$ of disasters-instead of the top $25 \%$ of disasters considered in the baseline regressions - the estimated coefficients tend to be less statistically significant. This suggests that a significant growth impact from disasters is far from certain and uniform across countries, but also that this effect is limited to the strongest among disasters, and then only in some countries and regions, especially the Caribbean and the Pacific. 


\section{APPENDIX}

Table A.1: List of Economies in Developing Asia and Subregions

\begin{tabular}{lllll}
\hline South Asia & East Asia & Southeast Asia & Central Asia & Pacific \\
\hline Afghanistan & China, People's Republic of & Brunei Darussalam & Armenia & Fiji \\
Bangladesh & Hong Kong, China & Cambodia & Azerbaijan & Papua New Guinea \\
Bhutan & Korea, Republic of & Indonesia & Georgia & Samoa \\
India & Mongolia & Lao People's Democratic & Kazakhstan & Solomon Islands \\
Maldives & & Kyrgyz Republic & Tonga \\
Nepal & & Myanmar & Tajikistan & Vanuatu \\
Pakistan & & Malaysia & & \\
Sri Lanka & & Philippines & \\
& Singapore & & \\
& & Thailand & \\
& Viet Nam & & \\
\hline
\end{tabular}

Source: Authors.

Table A.2: Disaster Impact in Developing Asia, 1980-2017

\begin{tabular}{|c|c|c|c|c|c|c|c|c|c|}
\hline \multirow[b]{2}{*}{ Disaster Type } & \multicolumn{3}{|c|}{ Developing Asia } & \multicolumn{3}{|c|}{ Central Asia } & \multicolumn{3}{|c|}{ East Asia } \\
\hline & Occurrence & Affected & Damage & Occurrence & Affected & Damage & Occurrence & Affected & Damage \\
\hline Flood & 1,570 & $4,334,004$ & 994 & 71 & 46,496 & 36 & 309 & $21,098,702$ & 3,332 \\
\hline Storm & 1,201 & $1,698,647$ & 590 & 9 & 12,010 & 31 & 368 & $3,729,327$ & 1,011 \\
\hline Earthquake & 426 & 633,736 & 1,228 & 34 & 41,982 & 60 & 142 & $2,007,247$ & 4,220 \\
\hline Landslide & 332 & 53,172 & 90 & 26 & 11,090 & 42 & 79 & 83,064 & 270 \\
\hline Epidemic & 282 & 29,173 & $\mathrm{n} / \mathrm{a}$ & 13 & 2,167 & $\mathrm{n} / \mathrm{a}$ & 16 & 3,641 & $\ldots$ \\
\hline Drought & 135 & $18,804,185$ & 1,080 & 7 & $1,232,167$ & 101 & 38 & $25,222,500$ & 2,355 \\
\hline Extreme temperature & 131 & $1,991,406$ & 1,894 & 10 & 374,223 & 840 & 20 & $6,925,927$ & 3,317 \\
\hline Volcanic activity & 76 & 56,713 & 86 & $\ldots$ & $\ldots$ & $\ldots$ & $\ldots$ & $\ldots$ & $\ldots$ \\
\hline Wildfire & 53 & 151,786 & 788 & 1 & 8,000 & $\ldots$ & 23 & 8,426 & 644 \\
\hline Mass movement (dry) & 20 & 1,082 & 5 & 2 & 400 & $\ldots$ & 7 & 1,369 & 8 \\
\hline Insect infestation & 6 & 200 & $\ldots$ & 1 & $\ldots$ & $\ldots$ & 1 & $\ldots$ & $\ldots$ \\
\hline
\end{tabular}


16 | Appendix

Table A.2 continued

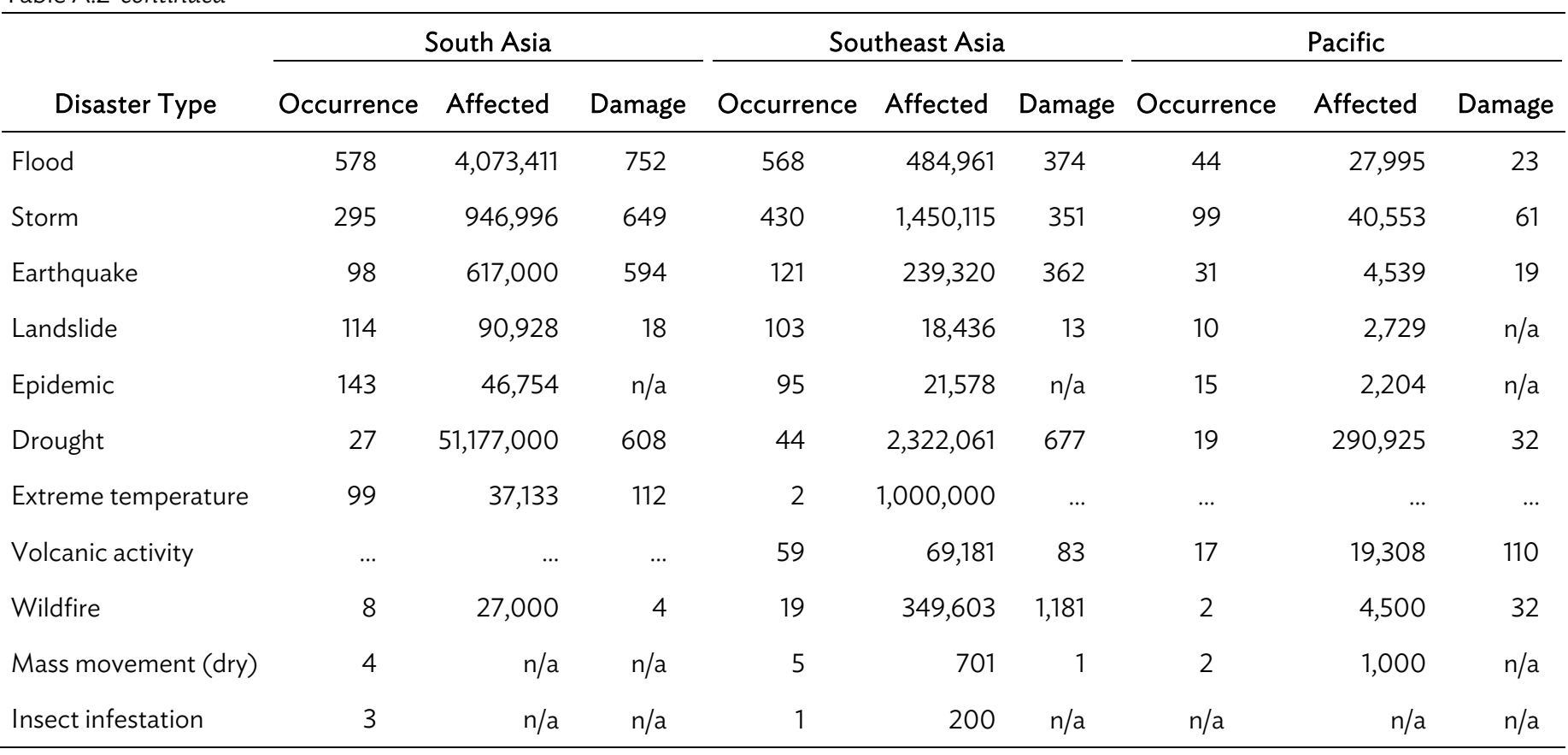

$\ldots=$ no data, Occurrence $=$ total number of disasters, Affected $=$ average number of people per disaster, Damage $=$ average damage and losses (\$ million). Sorted by descending occurrence in Asian Development Bank developing member countries.

Source: Authors.

Table A.3: Summary of Variables Used in Regression Analysis-Developing Asia Sample

\begin{tabular}{lccccc}
\hline Variable & $\begin{array}{c}\text { Number of } \\
\text { Observations }\end{array}$ & Mean & $\begin{array}{c}\text { Standard } \\
\text { Deviation }\end{array}$ & Minimum & Maximum \\
\hline GDP growth & 1,380 & 0.041263 & 0.065489 & -0.59573 & 0.494924 \\
Log (real GDP per capita) & 1,423 & 7.726909 & 1.162154 & 5.251812 & 10.99191 \\
Log (population density) & 1,601 & -2.395365 & 1.640548 & -6.8238 & 2.068852 \\
Log (inflation) & 1,207 & 4.683596 & 0.197043 & 4.333071 & 8.15291 \\
Trade openness & 1,263 & 0.984198 & 0.71289 & 0.001674 & 4.426188 \\
Terms of trade growth & 927 & 0.002928 & 0.099375 & -0.43496 & 0.965174 \\
Financial depth & 1,124 & 0.405729 & 0.388384 & 0.003351 & 2.33211 \\
\hline
\end{tabular}

GDP = gross domestic product.

Source: Authors. 


\section{Table A.4: Ordinary Least Squares Results with Severe Disaster Dummies}

\section{(a) World}

\begin{tabular}{|c|c|c|c|}
\hline Dependent Variable: Log (GDP Growth) ${ }_{t}$ & (1) & $(2)$ & (3) \\
\hline \multirow[t]{2}{*}{ Top 25\% intensity $y_{t}$} & -0.0025 & & \\
\hline & $(0.0019)$ & & \\
\hline \multirow[t]{2}{*}{ Top 25\% damage (\% of GDP) ${ }_{t}$} & & $-0.0043^{* *}$ & \\
\hline & & $(0.0019)$ & \\
\hline \multirow[t]{2}{*}{ Top $25 \%$ affected (\% of population) ${ }_{t}$} & & & $-0.0032^{*}$ \\
\hline & & & $(0.0019)$ \\
\hline \multirow[t]{2}{*}{$\log (\text { real GDP per capita) })_{t-1}$} & $-0.0391^{* * *}$ & $-0.0390^{* * *}$ & $-0.0392^{* * *}$ \\
\hline & $(0.0116)$ & $(0.0116)$ & $(0.0116)$ \\
\hline \multirow[t]{2}{*}{$\log (\text { population density })_{t-1}$} & 0.0049 & 0.0050 & 0.0050 \\
\hline & $(0.0160)$ & $(0.0160)$ & $(0.0160)$ \\
\hline \multirow[t]{2}{*}{$\log (\text { inflation })_{t-1}$} & $-0.0132^{* *}$ & $-0.0130^{* *}$ & $-0.0131^{* *}$ \\
\hline & $(0.0053)$ & $(0.0053)$ & $(0.0053)$ \\
\hline \multirow[t]{2}{*}{ Trade openness $s_{t-1}$} & $0.0489^{* *}$ & $0.0490^{* *}$ & $0.0489^{* *}$ \\
\hline & $(0.0201)$ & $(0.0200)$ & $(0.0201)$ \\
\hline \multirow[t]{2}{*}{ Terms of trade growth $_{t-1}$} & $0.0175^{* *}$ & $0.0174^{* *}$ & $0.0175^{* *}$ \\
\hline & $(0.0081)$ & $(0.0082)$ & $(0.0081)$ \\
\hline \multirow[t]{2}{*}{ Financial depth ${ }_{t-1}$} & $-0.0390^{* * *}$ & $-0.0389^{* * *}$ & $-0.0390^{* * *}$ \\
\hline & $(0.0132)$ & $(0.0132)$ & $(0.0132)$ \\
\hline \multirow[t]{2}{*}{ Constant } & $0.3555^{* * *}$ & $0.3539^{* * *}$ & $0.3561^{* * *}$ \\
\hline & $(0.0888)$ & $(0.0889)$ & $(0.0888)$ \\
\hline Time fixed effects & Yes & Yes & Yes \\
\hline Country fixed effects & Yes & Yes & Yes \\
\hline Number of observations & 3,848 & 3,848 & 3,848 \\
\hline R-squared within & 0.1637 & 0.1640 & 0.1639 \\
\hline
\end{tabular}

$\mathrm{GDP}=$ gross domestic product.

Notes: Time and country fixed effects are included but omitted for brevity. Standard errors in parentheses. ${ }^{*}=$ significant at $10 \%$,

${ }^{* *}=$ significant at $5 \%,{ }^{* * *}=$ significant at $1 \%$.

Source: Authors.

(b) Developing regions

\begin{tabular}{lccccc}
\hline $\begin{array}{l}\text { Dependent Variable: } \\
\text { Log (GDP Growth) })_{t}\end{array}$ & $\begin{array}{c}\text { Developing } \\
\text { Asia }\end{array}$ & Caribbean & $\begin{array}{c}\text { Central and } \\
\text { South America }\end{array}$ & $\begin{array}{c}\text { Middle East } \\
\text { and North } \\
\text { Africa }\end{array}$ & $\begin{array}{c}\text { Sub-Saharan } \\
\text { Africa }\end{array}$ \\
\hline Top 25\% intensity $t$ & -0.0052 & $-0.0196^{* * *}$ & -0.0009 & 0.0037 & -0.0013 \\
Top 25\% damage (\% of GDP) $t_{t}$ & -0.0017 & $-0.0208^{* *}$ & $-0.0085^{* * *}$ & 0.0082 & -0.0015 \\
Top 25\% affected population ${ }_{t}$ & -0.0054 & $-0.0198^{* * *}$ & -0.0020 & 0.0106 & -0.0025 \\
& $(0.0033)$ & $(0.0055)$ & $(0.0030)$ & $(0.0101)$ & $(0.0045)$ \\
Number of observations & 750 & 178 & 627 & 355 & 1,222 \\
\hline
\end{tabular}

GDP = gross domestic product.

Notes: Full results are omitted for brevity. Standard errors in parentheses. ${ }^{*}=$ significant at $10 \%,{ }^{* *}=$ significant at $5 \%,{ }^{* *}=$ significant at $1 \%$. Source: Authors. 


\section{(c) Developing Asia subregions}

\begin{tabular}{|c|c|c|c|c|c|}
\hline $\begin{array}{l}\text { Dependent Variable: } \\
\text { Log (GDP Growth)t }\end{array}$ & Central Asia & East Asia & Pacific & South Asia & Southeast Asia \\
\hline Top 25\% intensity ${ }_{t}$ & $\begin{array}{r}0.0099 \\
(0.0129)\end{array}$ & $\begin{array}{l}-0.0242 \\
(0.0205)\end{array}$ & $\begin{array}{r}-0.0177^{* * *} \\
(0.0039)\end{array}$ & $\begin{array}{l}-0.0038 \\
(0.0047)\end{array}$ & $\begin{array}{r}0.0057 \\
(0.0039)\end{array}$ \\
\hline Top 25\% damage (\% of GDP) & $\begin{array}{c}-0.0351^{* *} \\
(0.0145)\end{array}$ & $\begin{array}{l}-0.0033 \\
(0.0136)\end{array}$ & $\begin{array}{l}-0.0156 \\
(0.0126)\end{array}$ & $\begin{array}{r}-0.0081 \\
(0.0052)\end{array}$ & $\begin{array}{l}-0.0074 \\
(0.0065)\end{array}$ \\
\hline Top $25 \%$ affected population ${ }_{t}$ & $\begin{array}{r}0.0099 \\
(0.0129)\end{array}$ & $\begin{array}{l}-0.0242 \\
(0.0205)\end{array}$ & $\begin{array}{l}-0.0129^{*} \\
(0.0072)\end{array}$ & $\begin{array}{r}-0.0014 \\
(0.0040)\end{array}$ & $\begin{array}{l}0.0060^{*} \\
(0.0031)\end{array}$ \\
\hline Number of observations & 96 & 109 & 102 & 189 & 254 \\
\hline
\end{tabular}

GDP = gross domestic product.

Notes: Full results are omitted for brevity. Standard errors in parentheses. ${ }^{*}=$ significant at $10 \%,{ }^{* *}=$ significant at $5 \%,{ }^{* *}=$ significant at $1 \%$. Source: Authors.

\section{Table A.5: Generalized Method of Moments Regressions with above 50th Percentile Disaster Dummies}

\section{(a) World}

\begin{tabular}{|c|c|c|c|}
\hline Dependent Variable: Log (GDP Growth) $t$ & (1) & (2) & (3) \\
\hline \multirow[t]{2}{*}{ Top 50\% intensity $t_{t}$} & -0.0026 & & \\
\hline & $(0.0022)$ & & \\
\hline \multirow[t]{2}{*}{ Top $50 \%$ damage (\% of GDP) } & & -0.0027 & \\
\hline & & $(0.0027)$ & \\
\hline \multirow[t]{2}{*}{ Top $50 \%$ affected (\% of population) $t$} & & & -0.0027 \\
\hline & & & $(0.0022)$ \\
\hline \multirow[t]{2}{*}{ Log (real GDP per capita) $)_{t-1}$} & $-0.1027^{* * *}$ & $-0.1030^{* * *}$ & $-0.1029^{* * *}$ \\
\hline & $(0.0142)$ & $(0.0142)$ & $(0.0142)$ \\
\hline \multirow[t]{2}{*}{$\log (\text { population density) })_{t-1}$} & 0.0180 & 0.0186 & 0.0180 \\
\hline & $(0.0186)$ & $(0.0186)$ & $(0.0186)$ \\
\hline \multirow[t]{2}{*}{$\log (\text { inflation })_{t-1}$} & 0.0070 & 0.0070 & 0.0070 \\
\hline & $(0.0053)$ & $(0.0053)$ & $(0.0053)$ \\
\hline \multirow[t]{2}{*}{ Trade openness ${ }_{t-1}$} & $0.0585^{* * *}$ & $0.0586^{* * *}$ & $0.0586^{* * *}$ \\
\hline & $(0.0079)$ & $(0.0079)$ & $(0.0079)$ \\
\hline \multirow[t]{2}{*}{ Terms of trade growth ${ }_{t-1}$} & $0.0132^{* *}$ & $0.0133^{* *}$ & $0.0132^{* *}$ \\
\hline & $(0.0064)$ & $(0.0064)$ & $(0.0064)$ \\
\hline \multirow[t]{2}{*}{ Financial depth ${ }_{t-1}$} & $-0.0354^{* * *}$ & $-0.0352^{* * *}$ & $-0.0355^{* * *}$ \\
\hline & $(0.0122)$ & $(0.0122)$ & $(0.0122)$ \\
\hline Time fixed effects & Yes & Yes & Yes \\
\hline Number of observations & 3,666 & 3,666 & 3,666 \\
\hline $\operatorname{AR}(2) p$ value & 0.1948 & 0.2156 & 0.2038 \\
\hline
\end{tabular}

$\mathrm{AR}=$ autoregressive model, $\mathrm{GDP}=$ gross domestic product.

Notes: Time fixed effects are included but omitted for brevity. Standard errors in parentheses. ${ }^{*}=$ significant at $10 \%,{ }^{* *}=$ significant at $5 \%$, $* * *=$ significant at $1 \%$.

Source: Authors. 


\section{(b) Developing regions}

\begin{tabular}{lrrrrr}
\hline $\begin{array}{l}\text { Dependent Variable: } \\
\text { Log (GDP Growth) } t\end{array}$ & $\begin{array}{c}\text { Developing } \\
\text { Asia }\end{array}$ & Caribbean & $\begin{array}{c}\text { Central and } \\
\text { South America }\end{array}$ & $\begin{array}{c}\text { Middle East } \\
\text { and North } \\
\text { Africa }\end{array}$ & $\begin{array}{c}\text { Sub-Saharan } \\
\text { Africa }\end{array}$ \\
\hline Top 50\% intensity $t_{t}$ & -0.0016 & $-0.0181^{* * *}$ & -0.0036 & 0.0009 & -0.0012 \\
& $(0.0028)$ & $(0.0052)$ & $(0.0023)$ & $(0.0149)$ & $(0.0037)$ \\
Top 50\% damage (\% of GDP) $t$ & 0.0016 & $-0.0197^{* * *}$ & $-0.0117^{* * *}$ & -0.0019 & 0.0085 \\
& $(0.0028)$ & $(0.0059)$ & $(0.0028)$ & $(0.0176)$ & $(0.0072)$ \\
Top 50\% affected population ${ }_{t}$ & -0.0017 & $-0.0182^{* * *}$ & $-0.0045^{*}$ & 0.0037 & -0.0023 \\
& $(0.0028)$ & $(0.0053)$ & $(0.0023)$ & $(0.0167)$ & $(0.0038)$ \\
Number of observations & 713 & 168 & 605 & 336 & 1,174 \\
\hline
\end{tabular}

GDP = gross domestic product.

Notes: Full results are omitted for brevity. Standard errors in parentheses. ${ }^{*}=$ significant at $10 \%,{ }^{* *}=$ significant at $5 \%,{ }^{* * *}=$ significant at $1 \%$.

Source: Authors.

\section{(c) Developing Asia's subregions}

\begin{tabular}{|c|c|c|c|c|c|}
\hline $\begin{array}{l}\text { Dependent Variable: } \\
\text { Log (GDP Growth) }\end{array}$ & Central Asia & East Asia & Pacific & South Asia & Southeast Asia \\
\hline Top 50\% intensity $y_{t}$ & $\begin{array}{l}-0.0061 \\
(0.0077)\end{array}$ & $\begin{array}{r}0.0015 \\
(0.0083)\end{array}$ & $\begin{array}{l}-0.0085 \\
(0.0056)\end{array}$ & $\begin{array}{r}0.0055 \\
(0.0052)\end{array}$ & $\begin{array}{l}0.0084^{* *} \\
(0.0036)\end{array}$ \\
\hline Top 50\% damage (\% of GDP) $t$ & $\begin{array}{r}-0.0065 \\
(0.0113)\end{array}$ & $\begin{array}{r}0.0078 \\
(0.0088)\end{array}$ & $\begin{array}{l}-0.0115^{*} \\
(0.0061)\end{array}$ & $\begin{array}{r}0.0035 \\
(0.0040)\end{array}$ & $\begin{array}{l}-0.0027 \\
(0.0033)\end{array}$ \\
\hline Top $50 \%$ affected population ${ }_{t}$ & $\begin{array}{r}0.0013 \\
(0.0084)\end{array}$ & $\begin{array}{l}-0.0083 \\
(0.0095)\end{array}$ & $\begin{array}{l}-0.0085 \\
(0.0056)\end{array}$ & $\begin{array}{r}0.0008 \\
(0.0051)\end{array}$ & $\begin{array}{r}0.0065^{*} \\
(0.0034)\end{array}$ \\
\hline Number of observations & 90 & 105 & 94 & 180 & 244 \\
\hline
\end{tabular}

GDP $=$ gross domestic product .

Notes: Full results are omitted for brevity. Standard errors in parentheses. ${ }^{*}=$ significant at $10 \%,{ }^{* *}=$ significant at $5 \%,{ }^{* * *}=$ significant at $1 \%$.

Source: Authors. 


\section{Table A.6: Generalized Method of Moments Regression Results Using Alternative Specification for Intensity}

\begin{tabular}{|c|c|c|}
\hline $\begin{array}{l}\text { Dependent Variable: } \\
\text { Log (GDP Growth) } t\end{array}$ & Top 25\% Intensity ${ }_{t}{ }^{a}$ & Top 50\% Intensity ${ }_{t}{ }^{2}$ \\
\hline \multirow[t]{2}{*}{ World } & $-0.0047^{*}$ & -0.0026 \\
\hline & $(0.0027)$ & $(0.0022)$ \\
\hline \multirow[t]{2}{*}{ Developing Asia } & 0.0013 & -0.0016 \\
\hline & $(0.0029)$ & $(0.0028)$ \\
\hline \multirow[t]{2}{*}{ Central Asia } & 0.0143 & -0.0061 \\
\hline & $(0.0141)$ & $(0.0077)$ \\
\hline \multirow[t]{2}{*}{ East Asia } & -0.0069 & 0.0015 \\
\hline & $(0.0100)$ & $(0.0083)$ \\
\hline \multirow[t]{2}{*}{ Pacific } & $-0.0171^{* * *}$ & -0.0085 \\
\hline & $(0.0057)$ & $(0.0056)$ \\
\hline \multirow[t]{2}{*}{ South Asia } & -0.0014 & 0.0055 \\
\hline & $(0.0040)$ & $(0.0052)$ \\
\hline \multirow[t]{2}{*}{ Southeast Asia } & 0.0057 & $0.0084^{* *}$ \\
\hline & $(0.0037)$ & $(0.0036)$ \\
\hline \multirow[t]{2}{*}{ Caribbean } & $-0.0164^{* * *}$ & $-0.0181^{* * *}$ \\
\hline & $(0.0060)$ & $(0.0052)$ \\
\hline \multirow[t]{2}{*}{ Central and South America } & $-0.0098^{* * *}$ & -0.0036 \\
\hline & $(0.0029)$ & $(0.0023)$ \\
\hline \multirow[t]{2}{*}{ Middle East } & -0.0167 & 0.0009 \\
\hline & $(0.0300)$ & $(0.0149)$ \\
\hline \multirow[t]{2}{*}{ Sub-Saharan Africa } & -0.0031 & -0.0012 \\
\hline & $(0.0044)$ & $(0.0037)$ \\
\hline
\end{tabular}




\section{Table A.7: Rolling 5-Year Generalized Method of Moments Regressions with Severe Disaster Dummies}

(a) World

\begin{tabular}{|c|c|c|c|}
\hline $\begin{array}{l}\text { Dependent Variable: } \\
\text { Log (GDP Growth)t }\end{array}$ & (1) & (2) & (3) \\
\hline Top 25\% intensity ${ }_{t}$ & $\begin{array}{l}-0.0009 \\
(0.0029)\end{array}$ & & \\
\hline Top 25\% damage (\% of GDP) ${ }_{t}$ & & $\begin{array}{l}-0.0034 \\
(0.0039)\end{array}$ & \\
\hline Top $25 \%$ affected (\% of population) ${ }_{t}$ & & & $\begin{array}{r}-0.0008 \\
(0.003)\end{array}$ \\
\hline Log (Real GDP per capita) $)_{t-1}$ & $\begin{array}{r}-0.3434^{* * *} \\
(0.0293)\end{array}$ & $\begin{array}{r}-0.3439^{* * *} \\
(0.0293)\end{array}$ & $\begin{array}{r}-0.3436^{* * *} \\
(0.0293)\end{array}$ \\
\hline Log (Population density) $)_{t-1}$ & $\begin{array}{l}-0.0407 \\
(0.0331)\end{array}$ & $\begin{array}{l}-0.0407 \\
(0.0331)\end{array}$ & $\begin{array}{l}-0.0407 \\
(0.0331)\end{array}$ \\
\hline $\log (\text { Inflation })_{t-1}$ & $\begin{array}{r}0.0019 \\
(0.0056)\end{array}$ & $\begin{array}{r}0.0017 \\
(0.0056)\end{array}$ & $\begin{array}{r}0.0019 \\
(0.0056)\end{array}$ \\
\hline Trade openness $s_{t-1}$ & $\begin{array}{l}0.0704^{* * *} \\
(0.0088)\end{array}$ & $\begin{array}{l}0.0704^{* * *} \\
(0.0088)\end{array}$ & $\begin{array}{l}0.0704^{* * *} \\
(0.0088)\end{array}$ \\
\hline Terms of trade growth ${ }_{t-1}$ & $\begin{array}{l}-0.0001 \\
(0.0001)\end{array}$ & $\begin{array}{l}-0.0001 \\
(0.0001)\end{array}$ & $\begin{array}{l}-0.0001 \\
(0.0001)\end{array}$ \\
\hline Financial depth ${ }_{t-1}$ & $\begin{array}{l}-0.0051 \\
(0.0189)\end{array}$ & $\begin{array}{l}-0.0048 \\
(0.0189)\end{array}$ & $\begin{array}{l}-0.0052 \\
(0.0189)\end{array}$ \\
\hline $\log (\text { Aid })_{t-3}$ & $\begin{array}{r}-0.0075 \\
(0.005)\end{array}$ & $\begin{array}{r}-0.0077 \\
(0.005)\end{array}$ & $\begin{array}{r}-0.0076 \\
(0.005)\end{array}$ \\
\hline Time fixed effects & Yes & Yes & Yes \\
\hline Number of observations & 2,594 & 2,594 & 2,594 \\
\hline AR(2) $p$ value & 0.7942 & 0.7953 & 0.7929 \\
\hline
\end{tabular}

$\mathrm{AR}=$ autoregressive model, $\mathrm{GDP}=$ gross domestic product.

Notes: Time fixed effects are included but omitted for brevity. Standard errors in parentheses. ${ }^{*}=$ significant at $10 \%,{ }^{* *}=$ significant at $5 \%$, $* * *=$ significant at $1 \%$.

Source: Authors. 


\section{(b) Developing regions}

\begin{tabular}{|c|c|c|c|c|c|}
\hline $\begin{array}{l}\text { Dependent Variable: } \\
\text { Log (GDP Growth)t }\end{array}$ & $\begin{array}{l}\text { Developing } \\
\text { Asia }\end{array}$ & Caribbean & $\begin{array}{c}\text { Central and } \\
\text { South America }\end{array}$ & $\begin{array}{l}\text { Middle East and } \\
\text { North Africa }\end{array}$ & $\begin{array}{l}\text { Sub-Saharan } \\
\text { Africa }\end{array}$ \\
\hline Top 25\% intensity ${ }_{t}$ & $\begin{array}{l}-0.0033 \\
(0.0032)\end{array}$ & $\begin{array}{l}-0.0046 \\
(0.0081)\end{array}$ & $\begin{array}{l}-0.0032 \\
(0.0034)\end{array}$ & $\begin{array}{r}0.0068 \\
(0.0274)\end{array}$ & $\begin{array}{r}0.0035 \\
(0.0045)\end{array}$ \\
\hline Top 25\% damage (\% of GDP) $t$ & $\begin{array}{r}-0.0015 \\
(0.0037)\end{array}$ & $\begin{array}{l}-0.0141^{* *} \\
(0.0072)\end{array}$ & $\begin{array}{r}-0.0014 \\
(0.0039)\end{array}$ & $\begin{array}{r}0.005 \\
(0.0231)\end{array}$ & $\begin{array}{l}-0.0054 \\
(0.0108)\end{array}$ \\
\hline Top $25 \%$ affected population ${ }_{t}$ & $\begin{array}{l}-0.0018 \\
(0.0032)\end{array}$ & $\begin{array}{l}-0.0046 \\
(0.0081)\end{array}$ & $\begin{array}{l}-0.0009 \\
(0.0035)\end{array}$ & $\begin{array}{r}0.0089 \\
(0.0312)\end{array}$ & $\begin{array}{r}0.0033 \\
(0.0047)\end{array}$ \\
\hline Number of observations & 614 & 145 & 581 & 276 & 1154 \\
\hline
\end{tabular}

GDP = gross domestic product.

Notes: Full results are omitted for brevity. Standard errors in parentheses. ${ }^{*}=$ significant at $10 \%,{ }^{* *}=$ significant at $5 \%,{ }^{* *}=$ significant at $1 \%$. Source: Authors.

\section{(c) Developing Asia subregions}

\begin{tabular}{|c|c|c|c|c|c|}
\hline $\begin{array}{l}\text { Dependent Variable: } \\
\text { Log (GDP Growth) }\end{array}$ & Central Asia & East Asia & Pacific & South Asia & Southeast Asia \\
\hline Top 25\% intensity $y_{t}$ & $\begin{array}{l}-0.0093 \\
(0.0110)\end{array}$ & $\begin{array}{r}0.0023 \\
(0.0084)\end{array}$ & $\begin{array}{l}0.0177^{* * *} \\
(0.0061)\end{array}$ & $\begin{array}{l}-0.0102^{* *} \\
(0.0042)\end{array}$ & $\begin{array}{l}-0.0032 \\
(0.0039)\end{array}$ \\
\hline Top 25\% damage (\% of GDP) ${ }_{t}$ & $\begin{array}{r}0.0076 \\
(0.0116)\end{array}$ & $\begin{array}{l}-0.0142^{*} \\
(0.0084)\end{array}$ & $\begin{array}{r}0.0037 \\
(0.0084)\end{array}$ & $\begin{array}{r}-0.0209^{* * *} \\
(0.0062)\end{array}$ & $\begin{array}{r}0.0025 \\
(0.0048)\end{array}$ \\
\hline Top 25\% affected population ${ }_{t}$ & $\begin{array}{l}-0.0093 \\
(0.0110)\end{array}$ & $\begin{array}{r}0.0000 \\
(0.0077)\end{array}$ & $\begin{array}{l}0.0164^{* *} \\
(0.0065)\end{array}$ & $\begin{array}{r}-0.0106^{* * *} \\
(0.0041)\end{array}$ & $\begin{array}{r}-0.0017 \\
(0.0042)\end{array}$ \\
\hline Number of observations & 88 & 61 & 93 & 177 & 195 \\
\hline
\end{tabular}

$\mathrm{GDP}=$ gross domestic product.

Notes: Full results are omitted for brevity. Standard errors in parentheses. ${ }^{*}=$ significant at $10 \%,{ }^{* *}=$ significant at $5 \%,{ }^{* *}=\operatorname{significant}$ at $1 \%$. Source: Authors. 


\section{REFERENCES}

Aldrich, Daniel, and Yasuyuki Sawada. 2015. "The Physical and Social Determinants of Mortality in the 3.11 Tsunami.” Social Science \& Medicine 124: 66-75.

Arellano, Manuel, and Stephen Bond. 1991. "Some Tests of Specification for Panel Data: Monte Carlo Evidence and an Application to Employment Equations." Review of Economic Studies 58 (2): 277-97.

Arellano, Manuel, and Olympia Bover. 1995. "Another Look at the Instrumental-Variable Estimation of Error-Components Models." Journal of Econometrics 68 (1): 29-52.

Asian Development Bank (ADB). 2019. Asian Development Outlook 2019: Strengthening Disaster Resilience. Manila.

- - Asian Development Outlook Database. Inflation Rate in Asia and the Pacific. https://data.adb.org/dataset/inflation-rate-asia-and-pacific-asian-development-outlook-ado (accessed 7 December 2018).

Bello, Omar. 2017. "Disasters, Economic Growth, and Fiscal Response in the Countries of Latin America and the Caribbean, 1972-2010." CEPAL Review. 21: 7-29.

Cavallo, Edward, Sebastian Galiani, Ilan Noy, and Juan Patano. 2013. "Catastrophic Natural Disasters and Economic Growth." Review of Economics and Statistics 95 (5): 1549-61.

Cavallo, Edward, and Ilan Noy. 2011. "The Economics of Natural Disasters - A Survey." International Review of Environmental and Resource Economics 5 (1): 63-102.

Centre for Research on the Epidemiology of Disasters. Emergency Events Database. https://www.emdat.be/ (accessed 1 August 2018).

Elliott, Robert, Eric Strobl, and Puyang Sun. 2015. "The Local Impact of Typhoons on Economic Activity in China. A View from Outer Space." Journal of Urban Economics 88: 50-66.

Felbermayr, Gabriel, and Jasmin Groeschl. 2014. "Naturally Negative: The Growth Effect of Natural Disasters.” Journal of Developing Economics 111: 92-106.

Fomby, Thomas, Yuki Ikeda, and Norman Loayza. 2009. "The Growth Aftermath of Natural Disasters.” World Bank Policy Research Working Paper No. 5002.

International Monetary Fund (IMF). 2003. Fund Assistance for Countries Facing Exogenous Shocks. Policy Development and Review Department. Washington, DC.

- - World Economic and Financial Surveys. World Economic Outlook Database. https://www.imf.org/external/pubs/ft/weo/2018/02/weodata/index.aspx $\quad$ (accessed 7 December 2018).

Islam, Nazrul. 1995. “Growth Empirics: A Panel Data Approach.” Quarterly Journal of Economics 110 (4): 1127-70. 
Jaramillo, Christian. 2007. "Natural Disasters and Growth: Evidence Using a Wide Panel of Countries.” Document CEDE 2007-14.

Kahn, Matthew. 2005. "The Death Toll from Natural Disasters: The Role of Income, Geography, and Institutions." The Review of Economics and Statistics 187 (2): 271-84.

Lee, Dongyeol, Huan Zhang, and Chau Nguyen. 2018. "The Economic Impact of Natural Disasters in Pacific Island Countries: Adaptation and Preparedness.” IMF Working Paper No. 18/108.

Levine, Ross. 1997. "Financial Development and Economic Growth: Views and Agenda." Journal of Economic Literature 35 (2): 688-726.

Loayza, Norman, Eduardo Olaberría, Jamele Rigolini, and Luc Christiaensen. 2012. "Natural Disasters and Growth: Going beyond the Averages.” World Development 40 (7): 1317-36.

Mankiw, Nicholas G., David Romer, and David Weil. 1992. "A Contribution to the Empirics of Economic Growth.” Quarterly Journal of Economics 107 (2): 407-37.

Noy, Ilan. 2009. “The Economic Consequences of Disasters." Journal of Development Economics 88 (2): $221-31$.

- - . 2015. A New Non-Monetary Global Measure of the Direct Impact of Natural Disasters: Country Case Studies. Paper prepared for the 2015 Global Assessment Report on Disaster Risk Reduction. Geneva: UNISDR.

Noy, Ilan, and William duPont IV. 2016. "The Long-Term Consequences of Natural Disasters-A Summary of the Literature." Victoria University of Wellington Working Papers in Economics and Finance No. 02.

Noy, Ilan, Benno Ferrarini, and Donghyun Park. 2019. What Is and What Should Build-Back-Better be? Background paper for the Asian Development Outlook 2019. Manila: ADB.

Raddatz, Claudio. 2009. “The Wrath of God: Macroeconomic Costs of Natural Disasters.” World Bank Policy Research Working Paper No. 5039.

Skidmore, Mark, and Hideki Toya. 2002. “Do Natural Disasters Promote Long-Run Growth?” Economic Inquiry 40 (4): 664-87.

Strobl, Eric. 2011. "The Economic Growth Impact of Natural Disasters: Evidence from US Coastal Counties." Review of Economics and Statistics 93 (2): 575-89.

Toya, Hideki, and Mark Skidmore. 2007. "Economic Development and the Impacts of Natural Disasters.” Economic Letters 94 (1): 20-25.

World Bank. World Development Indicators. https://databank.worldbank.org/data/source/worlddevelopment-indicators (accessed 7 December 2018). 


\section{The Growth Impact of Disasters in Developing Asia}

This paper estimates the growth impact of disasters, with a focus on developing Asia and its subregions. It finds that severe disasters slow down annual growth in the small Pacific island countries by between 1 and 2 percentage points on average. This should come as no surprise, given these economies' extreme exposure, structural vulnerability, and small size relative to the footprint of major natural hazards. The growth impact is less clear for other regions and worldwide, mainly because disaster effects tend to be highly localized and get diluted in the context of cross-country regressions with nationwide growth as the unit of analysis.

\section{About the Asian Development Bank}

ADB is committed to achieving a prosperous, inclusive, resilient, and sustainable Asia and the Pacific, while sustaining its efforts to eradicate extreme poverty. Established in 1966, it is owned by 68 members -49 from the region. Its main instruments for helping its developing member countries are policy dialogue, loans, equity investments, guarantees, grants, and technical assistance. 